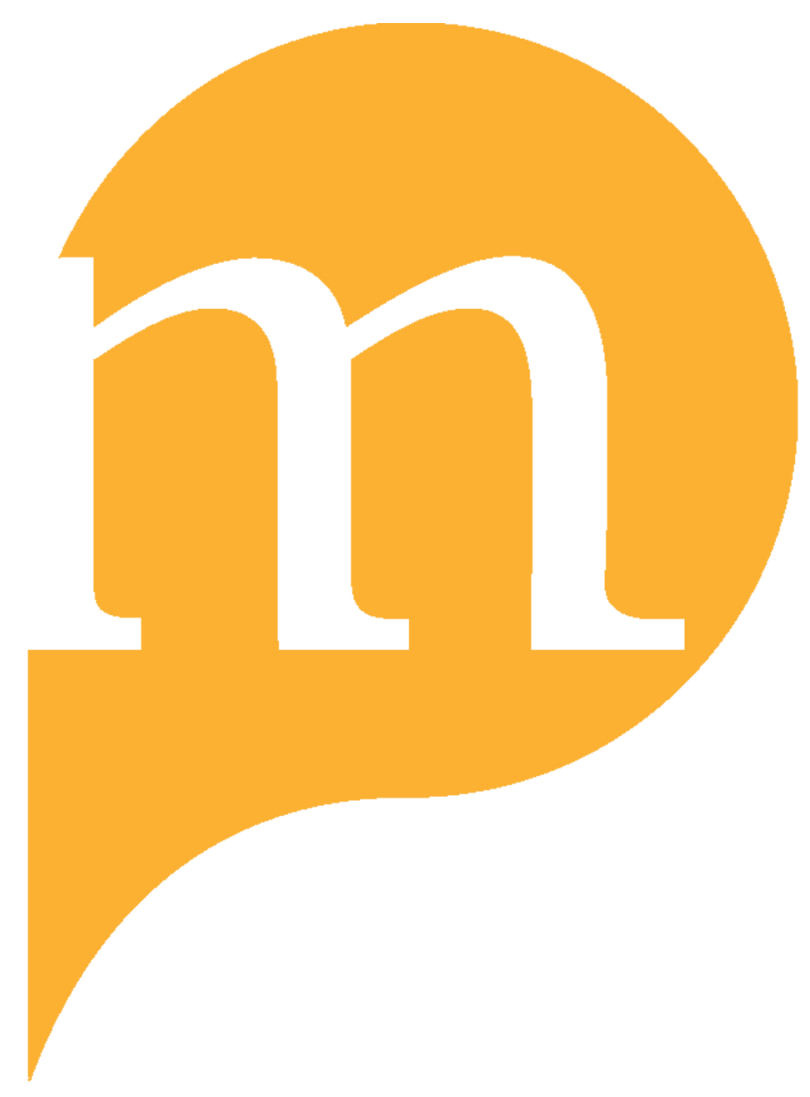

PROJECT MUSE 


\title{
Paradox of Diasporic Art from There: Antidote to Master Narrative of the Nation?
}

\author{
Hijoo Son
}

\begin{abstract}
There was the title of one of four projects exhibited at the fifth Kwangju Biennale held in South Korea in 2002. The name alludes to five of the oldest and largest overseas Korean communities: those in Brazil, China, Japan, Kazakhstan, and the United States. There curator, Yong Soon Min, chose twenty-four visual artists to represent the five locations, and their artwork showcased Korea's diasporic cultural production formulated by the historical migratory routes that have influenced the artists' lives and their art. There indicates a paradox of diasporic art. While some diasporic artists uphold the ideas of Korean national culture and belonging bound by homogeneity and blood ties, other artists directly challenge the meaning such narratives hold in their artistic expressions. As such, the show discussed multiple identity formations that resist dominant narratives, reflected differing experiences of class, gender, global, and national politics and indicated how the nation-state system is increasingly challenged by globalization. Yet, there are also artists who reinforce monocultural conceptions of national culture and cultural identity for diasporic subjects. In other words, diasporic art both undermines the master narrative of the nation at the same time as it reinforces them.
\end{abstract}

The fifth Kwangju Biennale held in South Korea in 2002 exhibited four large projects. Project Two: There, Sites of the Korean Diaspora showcased twentyfour artists from five of the oldest and largest Korean diasporic communities: those in Brazil, China, Japan, Kazahkstan, and the United States. There was thus an international large-scale exhibition and part of a biennale platform that provided a unique opportunity for cross-disciplinary analysis of artists, artwork,

Hijoo Son is assistant professor in the Department of History at Sogang University. Her current research interests include Korean migration history, visual culture, art theory, and related policy issues for a multicultural Korea. 
and cultural production within the field of Korean migration and diaspora studies. Although there were three components of Project Two: There, including the art exhibition curated by Min, a film festival curated by Paul Yi, and a symposium on Korean diaspora and art also organized by Min, this essay will focus on the production of the exhibition, the artists, and the artwork.

I draw on artwork, interviews, internal documents and recordings, press coverage, art critiques, artist statements, and exhibition catalogues to articulate the production of Korean diasporic art. By diaspora, I am referring to "ethnic minority groups of migrant origins residing and acting in host countries but maintaining strong sentimental and material links with their countries of origin - their homelands." Key to diasporic art is that artists explore a shared history of trauma, suffering, or displacement and affectively reconstruct and nostalgically re-imagine their historical memories of such events. The twenty-four artists, together, formulate a cultural history of this particular show's participants and the historical migratory routes that have influenced these artists' lives and art especially concerning cultural identity and transnational belonging. There indicates a paradox of diasporic art as it pertains to Korean artists. This paradox is evident in the case of groups of artists of similar generation, background, and experience as well as for individual artists. Whereas some diasporic artists uphold the ideas of homogeneity and blood ties, ideas central to the master narrative of the nation, other artists directly challenge the meaning such narratives hold in their artistic expressions. In other words, diasporic art both undermines dominant narratives of the nation at the same time as it reinforces singular conceptions of national culture, cultural belonging, and state affiliation for diasporic subjects. My findings thus show how ethnicity and nationality may be, on the one hand, true and real, but on the other, superficial and incommensurable measures in the search for oneness or commonality. In the academy, scholarship on diaspora and migration studies has to address, interact with, and account for these paradoxical shifts as they affect cultural identity and belonging.

The first part of this article traces the dominance of the master narrative of the Korean nation and depicts cultural production from the standpoint of the There exhibition. The artists, art practice, and activities reveal tensions underlying the master narrative that has constricted the history of Korean diaspora and their art. The organizational and curatorial process reveals the unevenness of the 2002 There exhibition in terms of its spatial orientation, print catalogues, curatorial decisions, reception, and other organizational processes. Such tensions and unevenness reflected the differing perspectives and opinions concerning overseas Koreans and diasporic art from the positions of the homeland-centered and overseas Koreans' views. Yet, the artists, artwork, and curators involved in There's production as well as the discourse produced through the exhibition engaged South Korean public opinion and the viewing audience in a dialectical cultural site and depicted an attempt at a radical indeterminate reading of art. 
In lieu of an open-ended reading of artists and artwork in a postmodern era where multiple aesthetic interpretations are always possible, a radical indeterminacy locates art in a specific setting and examines the activities surrounding the artwork. This historically specific, art-centered approach to the reading of artists and their art practice attempts an action-centered approach to art as it relates to the history of diasporic artists as well as the production of the There exhibition. The production unveils the constructed nature of national consciousness, what Naoki Sakai calls "regimes of fantasies" and cultural constructions that make up the essence of national culture and identity. ${ }^{2}$ But as Marx reminds us how false consciousness $i s$ consciousness, so too the constructed nature of national identity and nation-based forms of understandings and hierarchies are real and important to artists in Korean diaspora. A radical indeterminate reading of artwork and cultural productions of the There exhibition shows how unruly the questions of identity and belonging are in the context of Korea's history of colonialism and war, occupation, rupture from division, Cold War legacies, and the unevenness of global modernity.

As an analytical component of a radical indeterminate reading of art, I elucidate inter-relationships using a mesolevel analysis of migration. That is, the scale of identities discovered at the There exhibition brings alive movements of people on a mesolevel, a level of movement facilitated by family, kind, and other social and functional networks or communities that aid in the process of migrants' getting jobs, ascertaining cultural codes, and understanding how to adjust to and associate with all that is new. ${ }^{3}$ When migrants move, adjust, attempt to assimilate, and acculturate themselves in their new host societies, the family networks, social organizations (churches, school affiliations, trade organizations), and hometown-based or region-specific connections play significant intermediary roles in helping new immigrants adapt to unfamiliar environments, navigate strange terrains, and understand cultural and social codes. Hoerder's mesolevel analysis refers to the networks and communities that aid new migrants' adjustment to life in that new land. I want to add to a mesolevel platforms such as the international art exhibition, the prototype visualizations of artwork of these shows using digitization methods, as well as locally based art groups and associations such as the art group Areum of Japan.

The exhibition platform is equally a mesolevel of analysis in terms of cultural identity and affiliation because it not only showcases a group of artists in one place and at one time, it also allows viewers to make connections of these artists with others from vastly different backgrounds, especially backgrounds that pertain to the construction of artists' sense of self. Using digital methods, I further analyze these interrelationships using prototypical visualizations to re-represent the artwork previously showcased in There. ${ }^{4}$ What new relations may be conceived when retrieving visual images within a digital archive? How do or can these relations synergize what Jacques Rancière calls an action-centered theory of art? And finally, can visualizations of artwork enable exchange and facili- 
tate dialogue and discourse about identity between those who support nationcentered, singular positions and those who maintain cosmopolitan, transnational concepts of identity and belonging? If so, how influential are these cultural debates and dialogues especially within politically exigent regions such as the divided Korean peninsula?

\section{MASTER NARRATIVE OF THE NATION AND OVERSEAS KOREANS (CHAEOE TONGP'O $)^{5}$}

There was a transnational art exhibition that represented a significant moment within its local Kwangju setting as well as global art historical contexts. Many art critics, art historians, and curators are beginning to publish critical observations about South Korea's first biennale. ${ }^{6}$ However, this article focuses on the There production as a site critical of exclusive conceptions of identity and belonging, and as such, it provides a possibility of reshaping the understanding and perspectives of Korean diaspora from one that is hierarchical in nature to one that challenges these hierarchies on several fronts. First, the study of artists in diasporic communities challenges ideas of homogeneity (tanil minjok) and pure-blood relations (sunsu hyŏlt'ong) that have dominated discussions of overseas Koreans. These discussions, centered upon mainstream South Korean academic perspectives and public opinion, have largely confined the understanding of overseas Koreans within a master narrative of the ethnic nation. That narrative reifies a history of progress in order to overcome Korea's long and arduous history of suffering (sunan $\breve{u} i$ yŏksa). This history of suffering encompasses Korea's long experience with foreign incursions, beginning with the Han Chinese destruction of Old Chosŏn and establishment of four commanderies in northern Korea in the second century BCE, the Sui and Tang invasions of Koguryŏ in the sixth and seventh centuries, the Khitan invasions of the late tenth and eleventh centuries, the Mongol devastation in the thirteenth century, Hideyoshi's aggressions in the late sixteenth century, the Manchu invasions of the seventeenth century, the forced opening of Korea in 1876, colonization in the early twentieth century by Japan, and the ongoing American occupation of the southern half of the divided peninsula post-1945. In John Duncan's discussion of protonationalism in premodern Korea, he suggests that Korea's history of such foreign aggressions may have contributed to the formation of a sense of proto-national collective identity.

First, master narratives of Korean history portray the peninsula as having existed as a uniquely stable unit for more than 5000 years. ${ }^{8}$ Twentieth-century national and cultural identity discourse has produced a strong belief in the homogeneity of the Korean people and its pure bloodline. Although nationalist sentiments existed throughout the twentieth century, as earlier writings by Sin Ch'aeho (1880-1936) show, an epistemological break between post-1945 intellectuals and early twentieth-century thinkers shows how the former post- 
1945 group understood ethnic homogeneity as true and natural, whereas earlier writings exposited an acceptance of the more heterogeneous racial category that existed from the intermixing of races and ethnic stock.

The idea of homogeneity was coined in academic discourse in 1946 when nationalist scholar Yi Pyŏngdo (1896-1989) first introduced the term tanil minjok in an article titled "The Homogeneity of the Korean People" protesting the externally enforced partition of the nation. ${ }^{9}$ Yi defines minjok as those shared "master cultural features" (t'ŭksu munhwa naeyong) such as language, customs, thought, belief, morality, art, and literature that are historically constituted within a community. He carefully delineates how minjok is neither a race because it can be an intermixture of races, nor is it one nation's people reduced to sharing the mere political, economic, and legal apparatuses of one state. Yi's ahistorical pronouncement of tanil minjok argues for the distinct "special features" original and innate to a powerful master culture that has maintained Korea's unique cultural traits throughout its long history of political aggressions. The essence of Korean people or minjok, thus, helped the country survive past difficulties and overcome foreign incursions.

While Yi emphasizes a broad "master culture," others have emphasized a pure bloodline as an essentialist element of Korea's homogeneity. The idea of blood-kin relations extend back to Tan'gun, Korea's mythic progenitor and founder of the putative first Korean state of Old Chosonn in 2333 BCE. The blood tie has been inculcated in various ways during the twentieth century. The concept of homogeneity as expressed through its link to Tan'gun was a key doctrine of the new Taejonggyo religion, founded by Na Ch'ól in 1909. ${ }^{10}$ In 1914, Na's follower and student Kim Kyohŏn expressly defines the ancient Korean people in relation to Tan'gun as the paedal minjok (ancient Korean people) or paedal nara (ancient Korea) wherein the pae (培) means ancestors and tal (達) means splendor, so one literal translation of paedal minjok or nara could be "the people whose ancestors' splendor illuminates the world."11 Although this term refers to Ancient Korea, Ko Chosŏn (2333 BCE-104 BCE), no historical evidence indicates this term was actually used during ancient times. Korea's claim of being a homogeneous unit housing "splendid people" or paedal minjok was, then, a twentieth-century construction. ${ }^{12}$

The Tan'gun narrative is also part of the national historical struggle initiated by Sin Ch'aeho in the early twentieth century, but his work attempted to construct a true Korean historical consciousness (Han'guk yŏksa insik) through his re-writings of Korean history, not to claim a consanguineous link of all Koreans in the world..$^{13}$ More recently, Yi Kwanggyu writes that "we, the paedal minjok, carry on the tradition of an everlasting 5,000 year history following the birth of our progenitor Tan'gun and laying down roots in White Head Mountain." This was published on the first page of the first volume in a ten-volume series titled Segye ŭi Han minjok (Ethnic Koreans of the World) published in 1995 on the fiftieth anniversary of liberation to commemorate Korea's independence from 
Japanese colonial rule. Initially dedicated to Koreans residing abroad, these texts work to interlink overseas Koreans with the mythical progenitor Tan'gun, and in so doing, with the larger consanguineously related community of Koreans or what Yi refers to as the paedal minjok. ${ }^{14}$ Within this narrative, Koreans in diaspora are seen as pioneers (kaech'ókcha), interlocutors (woegyosajŏk), and future resources (mirae ŭi chasan) who form potential bases for the expansion of national power overseas. The hierarchy of the Korean nation then, especially in the postcolonial era, dominates the ways in which overseas Koreans or diasporic subjects are represented in mainstream South Korean public and/ or academic perspectives.

Second, as Korean migration history texts represent these diasporic groups as part of a larger consanguineously linked community, or as one author puts it, "finding nation outside the nation," 15 is it not the Korean nation that is the subject of study rather than the migrants themselves? The majority of postwar North and South Korean publications on case studies of the overseas Korean community or stories of pioneering immigrants and independence leaders evoke the difficulties of life in a strange land. Yet, they are ensconced in a historical framework that is descriptive, homogenizing, chronological, and nationalistic. Overseas Koreans are identified for the most part in terms of the assimilation processes at the destination country. It is assumed that the reader will empathize with sentiments of shared plight and ethnic oneness by locating overseas Korean communities within the broader context of national suffering of modern Korea. Migrants in these studies are treated as fellow compatriots supporting the efforts to rebuild and develop the Korean state and often lack agency. Yet, as part of minority communities, living in foreign places, perhaps no longer able to return to their homeland or not even wanting to, the stories of migrants as part of a larger Korean diaspora have rarely been recorded. And artists are especially able to captivate and fascinate the viewing audience by articulating the complicated ideas and difficult-to-describe conditions of living in diaspora. This artistic ability enables subsequent exchanges that surround the artwork and make this story of the production and artist-participants of There worth telling.

\section{SITUATING THERE}

There's production is a good starting point with which to analyze how the five distinct communities that Yong Soon Min believed best visually represented the Korean diaspora are also those overseas Korean communities that South Korea desires to incorporate into a larger ethnic nation beyond the nation. Wang-kyung Sung (Sŏng Wan'gyŏng) initially conceived of Project Two: There as part of the rationale for the 2002 Kwangju Biennale itself: to expand upon the localized identities of Kwangju and Asia. In addition to using "international" artists and 
alternative collaborations, he thought it an important idea to use Korean history, its history of migration, and the artists borne out of this movement. It helped that Sung had first met Yong Soon Min at the Havana Biennale in Cuba during the mid-1980s and then in New York many years earlier for the "Minjung Show" at Artist Space in 1988.

It is already difficult enough to try to bring a multiple experience to the viewing of art through the biennale, but we [curators] wanted to attempt to show this multi-oriented aspect of overseas Korean [Han minjok] artists. There is a certain way we [Korean people] are accustomed to seeing Korean diaspora, and we wanted to re-orient this viewpoint with an outsider's standpoint. ${ }^{16}$

Sung's attitude is indicative of a growing number of people who would like to understand difference and variety from "globalized historical experiences and standpoints. ${ }^{.17}$ Expanding the perspectives may be one of the only options to buffer against the oppressive hold of master narratives that still largely confine the discourse on overseas Koreans and cultural identity to the consanguineous link with the nation and its long history of suffering.

Min chose artists from Almaty, Kazakhstan; São Paulo, Brazil; Yanji, China; Osaka and the greater Kansai regions of Japan; and the two coasts of the United States to represent Korean diaspora at the 2002 Kwangju Biennale. Coming from the same era when Theresa Hak-Kyung Cha made strides in the U.S. art world, Min also was a pioneer visual artist, and her successful art practice combines the roles of artist, curator, and teacher. ${ }^{18}$ Min came of age when newly arriving immigrants, such as her family who emigrated in 1960, were more focused on establishing themselves professionally than on expressing themselves culturally. In the United States, second- and third-generation immigrants, who now choose professions outside of business, law, and medicine and foray into literature, dance, culinary arts, and even Hollywood, are producing a "burst of cultural forms." ${ }^{\prime 19}$ One must remember, however, that the diversity of Asian American artists' gains and access to modes of artistic representation was wrought out of the cultural politics of the 1960s and 1970s.

Contrary to expectations, in my first of three interviews with Min from 2002 to 2005 , she described the "mid-life art career lag" and loss of momentum she was experiencing, even though her vita includes numerous internationally acclaimed awards, grants, and commissions such as the Fulbright Fellowship (2010-11), Rockefeller Foundation Grant (2003), Anonymous Was a Woman Award (2001), City of Los Angeles Cultural Affairs Department Grant (1996), the National Studio Program of the Institute for Contemporary Art in 1991 (also known as P.S. 1), the Whitney Museum's Independent Studies Program in the early 1980s, and many other arts commissions, residencies, and visiting professorships. Min is certainly a recognized artist, and currently she is an associate professor in the Claire Trevor School of Studio Art at the University of California, Irvine. 
However, this lag may likely be part of a backlash many artists of color, including Min, faced within mainstream art circuits and international art markets in the aftermath of the highly criticized 1993 Whitney Biennale. In buildup to this culmination point, the 1980s was a formative era when artists of color, such as Min who was based in New York City at the time, drew upon their differing orientations in terms of politics, race, sexuality, and color. Such a politics of representation ascribed itself, self-admittedly, within a rubric of "identity art." 20 But just when multiculturalism had emerged as a popular, yet empowering mode of cultural production, it just as abruptly lost its political effectiveness due to the mainstream art world's backlash. Art critics conclude that multiculturalism hit a saturation point after Jean-Hubert Martin's Magiciens de la Terre (1989) show at the Pompidou in Paris and The Other Story (1989) and The Decade Show (1990) both in New York City and reached a denouement after the 1993 Whitney Biennale. ${ }^{21}$ In the 1990s, then, artists of color were hit with a double blow: multiculturalism's outmodedness in art circles, coupled with the slashing of funds for the National Endowment for the Arts and the dismantlement of the Arts Council in Great Britain. In other words, just at the point of entry when minority artists started to become visible, major funding sources dried up, and the art market itself lost interest in minority artists. Supporters of arts and cultural institutions looked toward a different direction. Min's own maturation as an artist during this era directly influenced her curatorial decision for There.

In addition to Min's own trajectory and experience as an artist, her art practice often takes an anthropological approach and visually depicts Korea's history of colonization, division, war, and occupation. I provide here a few samples from her expansive portfolio. Works such as Half Home (1986), Talking Herstory (1990), deColonization (1991), Chöngsindae (1992), and Defining Moments (1994) are titles of her body of work from the 1980s and 1990s that strongly interpolate a personal narrative of Korean history and incorporate her own memory of historical events. In Talking Herstory (1990), personal family photos reveal how her father's having worked at the U.S. Eighth Army military base in the aftermath of the Korean War brought her family to the United States. In Defining Moments (1994), a negative processed photograph of her body is inserted with historical dates such as $6.25,4.19,4.29$, and 8.15 to reference the start of the Korean War, which coincides with her birth date, the 1960 April Revolution against the authoritarian regime of Syngman Rhee (Yi Sŭngman), the Los Angeles Disturbance of 1992, and the date of Korean liberation from Japanese colonization, respectively. But since the turn of the millennia, she states her loss of momentum

is parallel to what is happening with the movement in Korea as well . . there is a lot of questioning now of the 1980s minjung [people's] movement and the kind of confidence they [Korean activists] might have had about reunification [of the two Koreas] which is no longer the case now. It is so much more of a complex situation now and 
after my trip to North Korea, I have to question my own assumptions and political beliefs/positions. It is all a big part of this big pause . . in my thinking. ${ }^{22}$

It is ironic that Min's loss of momentum and pause in thinking in the early 2000s coincided with the 2002 Kwangju Biennale's P_A_U_S_E theme. P_A_U_S_E takes its title from the need to reassess and reflect upon the last couple of decades of South Korea's trajectory through the end of the authoritarian regimes, the election of its first civilian government, the structural transformation of Kim Young Sam's (Kim Yŏngsam) globalization policies, and above all the economic "success" that catapulted South Korea to becoming the twelfth largest economy in the world by the late 1990s.

Min mentions "the movement" in our interviews, a term that reflects both minority artists' fight for visibility in the West and Korean activists' vital struggle to realize independence, unification, democracy, and justice on the peninsula. The fact that someone such as Min curated an international exhibition about artists of Korean diaspora inextricably places onto the plateau of a biennale the effects of both the denouement of multiculturalism in the United States and the minjung movement in South Korea. Indeed, she concludes her exhibition catalogue essay with an acknowledgement to both:

Discursive histories of earlier cultural confluences such as the Negritude movement, Harlem Renaissance, Multiculturalism, the Black Arts movement in Britain, and Minjoong [minjung] cultural movement in South Korea present viable models for the critique of new cultural formations in the diaspora. This exhibition of the artistic and cultural dimensions of the Korean diaspora can be best understood as a beneficiary of and an intervention into these enduring legacies. ${ }^{23}$

Even as she invokes diaspora, Min expresses concern about how this "diasporic framework displaces whatever gains multiculturalism has made." ${ }^{24}$ Is a diasporic orientation different because it provides a geographical expansion? Can it open up the conversation historically and comparatively? And what exactly enables diasporic art, and do these artists proclaim their identity as diasporic artists? Or does Min's framework of diasporic art not resonate with the artist-participants' art practices?

\section{Curators and Tensions}

Several tensions surface within There's production, including the overall artistic vision of Project Two from the standpoints of artistic director Wang-kyung Sung and Project Two curator Yong Soon Min, the exhibition's reception, on-site working conditions, organization, participant imbalance, and print representation. The first deals with the conception of Project Two. When Sŏng first asked Min to curate a show on Korean diaspora, he envisioned an anthropological approach 
to exploring the various communities of migrants living abroad. Although he gave Min artistic control over the conception and planning of Project Two, he imagined that it would examine the historical routes that Koreans traveled, both voluntarily and involuntarily, as they migrated abroad, parallel to the narratives of Korean migration set within master narratives of the nation as previously discussed. Min did carry out fieldwork for three weeks between August and November of 2001 with her research team including anthropologist Soo Young Chin, filmmaker Yoon Cho, and an undergraduate student assistant Miyoung Kim. ${ }^{25}$

Unfortunately, it seemed that for Sŏng and other Korean spectators, the exhibition itself did not fully reflect the body of fieldwork carried out at the local areas of diasporic art production. Yun Pŏmmo, art critic and professor at Kyewŏn University of Art and Design, asked the following question in his critique of the 2002 There show: "Exactly what in the world was the motivation for such an exhibition space? It was a shame . . " He goes on to hypothesize that perhaps it was because Min could not speak Korean that she was unable to utilize the space and understand the domestic audience. ${ }^{26}$ Rather than being guided by a trajectory of migration history in chronological time, or a Cartesian exhibition space centered on units of nation-states, Yun may have taken the complex of affects and motives instead of reducing the show's merit to a question of language capabilities or of misreading the diasporic theme as a nation-centered one.

Yun's critical review, thusly, lambasts There as part of the "worst Kwangju Biennale." ${ }^{27}$ Since the 2002 exhibition, from observations in informal meetings and interviews with curators, art critics, and artists in South Korea, I believe it is fair to say that people were not enraptured by There, and more than anything most Korean spectators wanted more explanation about this uneven grouping of artworks. ${ }^{28} \mathrm{An}$ independent observer and art history student at the time of the show and currently associate curator at New York's Museum of Modern Art, Doryun Chong also, like Yun, did not initially understand why a diasporic theme was even a centralizing principle and wondered if the show will be considered a throwback to multiculturalism that is, as mentioned above, the same era in the 1980s and 1990s during which time Min came of age in New York City. There's film festival organizer Paul Yi, producer of E Pictures and organizer of the first three Pusan film festivals, also noted that There was a show about identity. ${ }^{29}$ Chong recalls the stark unevenness of Min's Project Two: There juxtaposed to Project One: $P_{-} A_{-} U_{-} S_{-} E$, and this uneven aspect is the first thing he noticed and the last thing that lingered in his thoughts. One reason Chong believed There was still the most interesting of the four projects is because it was located historically and worked against the "flippant nature of [biennales] and globalism." On this, he states that "if the modern history of Korea is defined by atrocities and warfare or as a product of disabling paradoxes, this exhibition deals with the people who experienced these, in terms of their movement. Why did they [migrants] end up 'there' and why did they leave 
[Korea]; their existence 'there' goes back to the paradoxes on the peninsula that led them 'there' in the first place." ${ }^{30}$

The material, budgetary, and participant imbalance between Project One and Projects Two, Three, and Four presents other tensions within the physical on-site exhibition layout of the 2002 biennale. In particular, one immediately notices the marginalized space of the There show, since it shared the permanent Kwangju exhibition halls with Project One versus Project Three and Four's off-site exhibition spaces. There only took up one of the seven galleries, at the corner end of one of the exhibition halls. Although I was unable to attend the 2002 exhibition, this uneven feature emerges again and again from diagram maps of the exhibition layout to the description of the exhibition space and from interviews with curators, set designer of Project Two Ronald Stroud, and other artists. Moreover, in catalogue print format, Project One's catalogue included two dense volumes whose translations were clear and well done, compared to Project Two, Three, and Four's less-dense catalogues.

In conjunction with the exhibition itself, Min had organized an international symposium including speakers from abroad in addition to the artist-participants of the show to discuss There's production, intent, and meaning. Just a few days before, the scheduled symposium was canceled by the Kwangju Biennale Foundation without any explanation. After some back-and-forth between the Kwangju organizers and the diaspora organizers/participants, the symposium did end up taking place entirely in English, albeit with a smaller and mostly foreign audience. ${ }^{31}$ If this symposium had been attended by the South Korean audience, perhaps the manqué explanations would have been provided and a better understanding of the show's diasporic theme and uneven visual representation could have been addressed. But the question still remains, why and how could an international symposium be canceled without reason? This query also adds to the tension from the standpoint of There's production. ${ }^{32}$

Another point of criticism stemmed from the fact that ten of the twenty-four participants were young artists from the United States. Altogether, there were two artists each from Kazakhstan, China, and Brazil, seven from Japan, ten from the United States, and one artist from South Korea. The U.S-heavy focus was a point of criticism of the There project waged by Korean critics and others. Indeed, one of the motives behind the production of the 2004 Korean Diaspora and Arts Symposium in Tokyo initiated by Kyongsik Suh (Sŏ Kyŏngsik) was in response to the inadequate portrayal of Korean diasporic artists in There.

One final point of tension concerns the naming of Project Two. Why was Min's project not simply titled "Korean Diaspora"? When asked this question, Min immediately responded that the "Kwangju people" did not want to use the term. Sung is careful in stating that he does not recall exactly how Project Two's name was determined, but if there were disputes with the coordinating committee, it was that "diaspora" was not a familiar term in the Korean lexicon. My own experience with using this term leads me to believe Sung's 
explanation. When I co-founded the arts group Han Diaspora and began coordinating multi-media art exhibitions in South Korea fifteen years ago, diaspora was certainly a foreign idea in urban Seoul. In doing the press junkets for the three years of production from 1996 to 1998, for example, I recall explaining the meaning, the concept, and examples of "diaspora" repeatedly for the mainstream South Korean media, ${ }^{33}$ and only when I described the show in terms of overseas Koreans, haeoe tongp'o, or international adoptees, did the reporters nod in comprehension. What becomes clear is that even as the exhibition's main title There may have been suggested by Kwangju organizers, the subtitle Sites of the Korean Diaspora in its English iteration, the term diaspora remained. But for the Korean audience, it was translated as isan ŭi ttang or "land of displacement." Naming the show There and not Korean Diaspora indicates the discursive discontinuity between those who talk about overseas Koreans from a South Korean perspective and those who discuss diaspora from, in this case, a U.S. standpoint. Recently, however, diaspora has become more popular, as is evident in the number of publications discussing this term. ${ }^{34}$

Even given the various unevenness and tensions of the 2002 exhibition, Sung continues to articulate the four projects as "democratic in its equal parts and equal importance," even when an inequality in structure both at the exhibition space and the catalogue publication level is clearly noticeable. It is as if Sung, as artistic director of the entire 2002 biennale, and Min, as the curator of There, were working from different premises. That is, whereas Min aimed to show what she describes as fluidity in artists' subjectivity, Sung envisioned the representation of a diasporic history that would incorporate the legacy of suffering and the unique position of a divided country. The unmet expectation meant that for Sung, the overall collection did not help us better understand overseas Koreans. The tension reflects a contradiction in perspectives because Min did not restrict the understanding of identity to be configured in sole relation to a homeland. Min's aversion toward fixity meant that she considered her curatorial decision with "no overarching vantage point from which the diaspora is to be considered." ${ }^{35}$ What this inequality does reveal is that diaspora and diasporic identities still remain within a space of shadows. As the treatment of overseas Koreans is restricted within the confines of the master narrative of the nation, so too does diasporic art remain in the shadow of "international" artists.

The 2002 Project Two: There and the strains and tensions involved in its production serve as critical and useful sites for discussing diasporic art in two ways. On the one hand, the social process involved in diasporic art and its production incorporates local politics and histories - both Korean and diasporic-into a global exhibition, spatially expands the framework from which the artists come and where art is made, and thus results in a multiplicity of experiences, expressions, and associations, which leads to an action-centered approach to art. On the other hand, in the context of the entire exhibition, as suggested by the margin- 
alization of There in its reception, discourse, and physical location, a diasporic consciousness cannot take center stage; instead, it becomes physically and metaphorically confined to a marginalized space in Korea's understanding of its history, culture, and society.

\section{Kwangju: From City of Revolt to City of Culture}

Talk of Kwangju may elicit one of several reactions from those who know something about South Korea and its metropolitan regions, but foremost in recent historical memory, Kwangju is the place where victims suffered and heroes arose during and after the May 18 Kwangju Uprising in $1980 .{ }^{36}$ The Kwangju Uprising of 5.18 (o-il-p'al) was incited when riot police cracked down on pro-democracy students in front of Chŏnnam University. The use of numbers from dates such as 5.18 (o-il-p'al or five-one-eight) is a common practice in South Korea to demarcate historical events. This practice has even flowed into the U.S. context, for example, as the L.A. Riots are often called 4.29 ( $s a-i-k u$, or four-two-nine), another reason for Yong Soon Min's own use of date demarcation in her piece Defining Moments.

Lasting ten days, some 3,000 paratroopers sent from Seoul quelled the unrest and enforced President Chun Doo Hwan's (Chŏn Tuhwan) decree of martial law. Given the city's population of 730,000 in 1980, the small toll of the "official" figures of 500 civilian dead and 3,000 injured remain highly contested. Kwangju is also known as the political base of the former President and Nobel Laureate Kim Dae Jung (Kim Taejung), and the rival city of Pusan, a city that touts itself as the center of culture, democratic struggles, and international exchange. However, the Kwangju Uprising of 5.18 unequivocally remains the event that has circumscribed the city's identity.

The lingering questions and solemn shadows of the Kwangju Uprising left an indelible scar on the people of Kwangju. Remembering and recording what happened is an on-going project that memorializes the event and makes heroes of martyrs and everyday folk who took part in the fight for democracy. With such a legacy, Kwangju, as a site for artistic manifestations and cultural productions, happens from a local, off-center space-an evocative space where minor narratives may emerge. Indeed, the remembering of the Kwangju Uprising discursively and in public spaces has influenced the locality so much that the singed memories of Kwangju grew into what some label a "5.18 industry" supporting the publications, cultural events, public hearings, and laws that have been promulgated toward memorializing the tragedy. ${ }^{37}$ In a far larger (in scope) but still comparable example, Norman Finkelstein tenaciously delineates forms of the economic, ideological, and moral exploitation of the Holocaust in The Holocaust Industry, a construct, he argues, that has accrued "dividends" in large (state of Israel) and small (individual compensation) forms by capitalizing upon victimhood. ${ }^{38}$ 
The transformation of 5.18 from tragedy, into the fight for democratic struggle to local identity politics that then prevails as a celebration of culture on a global scale is part of the process of "overcoming 5.18" that parlays the public memorial into cultural commemoration. The Kim Young Sam administration first pumped funds into events commemorating the Kwangju Uprising, and studies show that the Kwangju Biennale was initiated by the central government and supported by local governments in an effort to transform Kwangju's image from a city of resistance to a "city of art." 39 The Korean government even ordered various ministries to help the Kwangju local government advertise its biennale. Only after Kim Young Sam himself visited and officially sanctioned his support for the event did major media outlets cover it. ${ }^{40}$ In this fashion, even local history, however minor and off-center, aligned with the national task of overcoming the history of peninsular struggles.

One must remember, however, that regional identity cannot always be subsumed under national identity. Ho-Ki Kim and Jongil Park remind us of the contention between a strong regional identity and state-dominated nationalist discourse. State theorists argue that the relationship between regionalism and ethnic nationalism is constituted by the oppositional claim that strong nationalism and national identity weaken regionalism and regional identity, or vice versa, that is, strong regional or ethnic identity make nation-state building difficult. However, both theories prove to be untrue in South Korea. Kim and Park understand regionalism as a consequence of modernization and democratization and underline the multiple, thus multi-regional, claims toward national identity in Korea. ${ }^{41}$ I read the launching of South Korea's first biennale in 1995 in the city of Kwangju as part of its own transformation into a city of arts and culture and as evidence of segyehwa, or globalization transitions, taking place at a local level. The memory of 5.18 has earned a positive reaction, and the public memorial has become not only commemorative but also culturally celebratory and economically profitable. ${ }^{42}$

One historical reason Kwangju experienced political turmoil is that during the late twentieth century it had largely been left out of industrial growth in the contemporary period. Topographically, the agricultural sector has always been strong due to regional soil conditions. Scholars often note that the people of the southern Chŏlla region, on the whole, did not participate in the 1919 March First movement due to their favorable economic profits from rice production. However, in the postwar period and especially during Park Chung Hee's (Pak Chŏnghŭi) export-oriented industrialization drive of the 1960s and 1970s, Kwangju and the surrounding region's urbanization did not progress in comparison to the rest of the country. ${ }^{43}$

By the mid-1990s, amid a significant shift in economic structures, discourses of globalization or segyehwa began to reflect a period of changing South Korean views on several registers. First, the end of the Cold War (outside of a still-divided Korea) brought about political realignments on a global scale that led to a gen- 
eral thawing of relations between North and South Korea that led to the muchanticipated Inter-Korean Summit of 2000 between Kim Dae Jung and Kim Jong Il (Kim Chŏnil). Second, major economic shifts, created for the emergence of multinational corporations, and changes in economic relations globalized South Korean capital (again) and made South Korean firms themselves transnational investors. These shifts are important not only in terms of South Korea's relationship to its overseas communities and its incorporation of "returnee" Koreans from abroad but also in terms of the growing presence of foreign migrants living and working in South Korea in recent times.

Third, globalization, or segyehwa, and its ensuing government policies have effected significant changes in how South Korea views its overseas Koreans. Samuel Kim defines globalization as "a series of complex, independent yet interrelated processes of stretching, intensifying, and accelerating worldwide interconnectedness in all aspects of human relations and transactions such that events, decisions and activities in one part of the world have immediate consequences for individuals, groups, and states in other parts of the world."244 The Kim Young Sam administration decided in early 1995 to keep the Romanized form for globalization, segyehwa, and specified one official connotation of segyehwa and the ethnic nation stating that "globalization must be underpinned by Koreanization." ${ }^{45}$ Similar to another analyst's call to "reconnect" with the 55 million overseas, President Kim's statement envisions a potential strength to be found in overseas Koreans in its globalization drive. ${ }^{46}$ More than simple economic liberalization that Westerners interpret as "globalization," segyehwa has a far more comprehensive reach into politics, society, and culture. In this context, the Kwangju Biennale played an instrumental role in bringing about this transformation both by providing an international stage to present Korean culture to the larger art world and by globalizing Kwangju.

\section{The 2002 Kwangju Biennale}

The 2002 exhibition was no exception in how the show partook in the cultural commemorations of the 5.18 industry, and in tribute to the city, the biennale's artistic director Wang-kyung Sung, chose a "democratic" distributed layout to present the collection. Sung is an art critic and formerly a professor of art criticism and curatorial studies at Inha University. He co-curated Project One: $P_{-} A_{-} U_{-} S_{-} E$ along with Hanru Hou and Charles Esche. ${ }^{47}$ Hou is currently director of exhibitions at San Francisco Art Institute. Esche is a senior research fellow at Saint Martins and director of Van Abbemuseum in Eindhoven, Netherlands. All Kwangju Biennale exhibitions before and after the 2002 show took place at the permanent Kwangju exhibition halls and the surrounding park that lie on the northwest outskirts of the city. But the four projects presented in 2002 took place in different venues. Project One: $P_{-} A_{-} U_{-} S_{-} E$ and Project Two: There were housed in the main exhibition halls. To give an idea of the size of Project One, a 
total of ninety-two groups, collaborations, or individual artists presented a mixture of formats: eighteen pavilions, twenty-six alternative spaces, and various individual artists' installations within six galleries both indoors and outdoors.

Projects Three and Four, meanwhile, were located in specific locations around the city, a move considered a curious curatorial decision. Rather than the Venice Biennale's format of thirty permanent national pavilions, the Kwangju Biennale in 2002 presented four projects, each with its own curator, theme, and layout. In addition to being in charge of the biennale as a whole, Sung alone curated Project Three: Stay of Execution, a site-specific show exhibited in a restored military police building located on the grounds of May 18 Liberty Memorial Park. The May 18 Liberty Park is one of two memorial parks in the new city of Sangmu (Sangmu sindosi), an urban renewal project in Kwangju. Hyŏngjŏng Kim, an architect, curated Project Four: Connection, which took place in an old, non-functioning train station and an adjacent railroad located in the southeastern section of the city. This type of distributed format is different from historical precedents of biennales.

For Sung, the spatial distribution of the 2002 Kwangju Biennale across the city worked because it created counter-hegemonic structures for intercultural networking. He asserts that in this manner, the latter also became non-homogenizing structures, opposite to biennales that are accused of cultivating a culture of spectacle and resistant to the evaluative system dictated by the cultural logic of global capital. After all, no art fair, that precedes or follows the Kwangju Biennale, provides a market where, traditionally, most of the buying and negotiating takes place at biennale sites, such as the art fairs at the Venice Biennale. Furthermore, the concept of extending the exhibition into local areas of political significance in Kwangju presented artistic perspectives about the hyonsil, or reality, of the city. Sung emphasized the need to present the hyŏnsil on several occasions to justify his curatorial decisions, and in the Korean art world, this term is circumscribed within a historicity of the minjung movement. ${ }^{48}$ Artists involved in the democracy struggles published a quarterly journal titled Hyonsil kwa parón (Reality and Utterance) for just over ten years in the 1980s and 1990s, and Sung chose many of these, now older artists, from this group for Project Three. Therefore, Kwangju's urban renewal projects became one point of recognizing the locale within an international exhibition. The cultural production of the distributed format fosters yet another method toward accessing historical memory of Kwangju in a celebratory fashion.

\section{DIASPORIC ART: ANTIDOTE TO MASTER NARRATIVES?}

To examine what Sung described as "outsiders' standpoints," I turn to the artists, artwork, and activities to reflect upon the outsider or minor diasporic narratives in contrast to the master narrative of the nation. Two main methodological con- 
cerns are important to discussing the social dimension of art and its cultural production. First, each art piece and each artist's practice exists within a structure of social relationships, and the tensions of curating a biennale production such as There imbues such social and human dimensions. This approach positions artists and their work as catalysts in a sphere of social activities where cultural production takes on added significance in light of their politically, communally, and individually situated functions. Alfred Gell goes so far as to claim art to be "persons" themselves in the sense that social networks, that form around the vicinity of the art object and surround particular artworks in specific interactive settings, mediates social agency. ${ }^{49}$

The second aspect of methodological concerns attempts to argue that art is an antidote to the master narrative of the Korean nation. The cultural production of the There show exemplifies the possibility of a provisional act of emancipation from dominant narratives, constituted by cultural equality. Equality does not refer to a founding ontological principle (i.e., all things equal or equality for all), but to a presupposition that Jacques Rancière defines as a "condition that only functions when it is put into action." ${ }^{50}$ Rancière implies equality exists within an "aesthetic regime," referring most particularly to a certain cultural equality that premises its existence on the reconstitution of the hierarchical system for fine arts. ${ }^{51}$

"Equality put into action" best describes the various activities in which artists must participate as part of a regime of art. This regime is premised on the idea that an analysis of art and artists cannot be separated from the history of social relations that informs the art-making. Alfred Gell helps us to see that "art objects come together with people and exist by virtue of the social relations amongst people through things. ${ }^{.52}$ There are several important characteristics to this regime of art that incorporates an action-centered approach. First, artists are cultural agents who make work about something and for an audience somewhere; therefore, an artists' intentionality is necessarily part of the art's agency. Second, art was showcased in multiple locations, and the routes of its own travel further extend the network of people and things that surrounds the art. In this sense, the production of art involves social activities that surround the vicinity of the art, referring to multiple locations: where it was made, installed, or constructed, where it has been shown, where it was collected, and what was written about it. Finally, the awareness of the mediatory role of art - the social relations that surround its vicinity within specific, but numerous, interactive settings - thus includes the artist, artwork, exchange, reception, and discourse. ${ }^{53}$

For example, the curatorial process, as I see it, was an action-centered approach that took Yong Soon Min, Soo-Young Chin, Yoon Cho, and Miyoung Kim to Almaty, Kyoto, New York, Osaka, São Paulo, Seoul, Tokyo, and Yanji, as well as Kwangju. The process included not only studio visits with the artists but also field site visits within the local Korean diaspora communities. The action-centered approach toward a regime of art equally involves my work as ethnographer, 
interviewing artists in-person and via other correspondences, visiting the sites of production in Kyoto, Los Angeles, New York, Osaka, Tokyo, Yanji, and Seoul and collecting visual material, especially by less-established and unknown artists from the more remote areas. The complex of social mediations involved in art production including the artist, curator, viewer, researcher, and history of the local production sites not only brings light to the differing histories of social relations in the specific regions where Koreans in diaspora reside but also creates new social relationships. The latter become critical components of the actioncentered, anthropological theory of art and part of an antidote to master narratives of the nation because of the diverse network of constituencies involved in the meaningful work of exchange, analysis, and discourse.

Another digital form of the antidote to master narratives is expressed in visualizations that re-show art and artists and retrieve information from a digitized primary archive. The visualization of digital assets - including paintings, maps, video footage, interview transcriptions, and digitally recorded talks - manifests what interrelationships exist within, among, and beyond sites of cultural production for There. The visualizations of the composite group of artwork shown at There, thus, uses computing methods to re-represent the artwork and retrieve the social relations and spheres of social activities of the twenty-four artists based upon reception, exchange, discourse, and all other artist- and art-related attributes. ${ }^{54}$

As there were twenty-four artists, the discussion of the artists and artwork in Min's catalogue essay revolves around four themes: landscape, history/politics/ society, gender and sexuality, and abstraction. ${ }^{55}$ The following section on diasporic art will limit the discussion to eighteen of the artists, but in addition to the categorization of these artists into thematic structures, this article focuses on conceptual and theoretical considerations to treat the ideas to which these migrant-cum-artists most gravitate as diasporic artists: loss of homeland, historical memories of loss, nostalgic recollection, and narrativization of the past within a regime of art wherein cultural production takes to task the necessity of equality in action. As the conceptual and theoretical concerns of a regime of art remain foremost on this author's mind, my discussion will not categorize each artist in each instance within the same theme or light as Min does in her catalogue essay "Certain Latitudes." Most important is my argument that whereas some artists from There present homeland, loss, and nostalgia narratives as ideas that serve the project of nation-building in the twentieth century, other artists undermine this thesis through artistic practices that resist, subvert, or reject altogether any dominant ideology. In other words, by examining diasporic art, I locate art that reinforces the master narrative of the nation while other art practices simultaneously challenge it.

\section{Landscape}

The examination of landscapes presented at the There exhibition draws from critical frameworks to show a mixture of mediums, style, function, and composi- 
tion. Octogenarian Hee Man Suk was the oldest (1914-2003) of the twenty-four artists. The function of his numerous landscapes (oil on canvas medium) declares the importance of scenes of daily life, Manchurian landscapes, and family scenes and shows that even depictions of individual human subjects were prized and venerated as part of landscape scenes. His landscape paintings illustrate his nostalgic visions of his hometown of Musan, Northern Hamgyŏng Province, his pristine visual depictions and recollections of his home region of Manchuria, specifically Yanbian Autonomous Prefecture of the Korean minority in China and the other surrounding Manchurian regions in Heilongjiang, Jilin, and Liaoning provinces. Suk's life can be largely categorized into several eras: his early childhood in Northern Hamgyŏng Province (1914-31), migration to Manchuria and his development and interest in art (1931-35), his studies abroad at the Tokyo School of Fine Arts (Tōkyō Bijutsu Gakkō, 1935-38), ${ }^{56}$ his art-related activities back in China before the Cultural Revolution (1939-65), banishment in work camps during the Cultural Revolution (1966-78), and post-Cultural Revolution art making and teaching activities (1978-2003). ${ }^{57}$ The untitled piece Yong Soon Min chose for the 2002 show was a vase of flowers picked out from the large body of depictions of natural flora that express, for Suk, equanimity (figure 1). Given Suk's tumultuous migratory route that included his having lost his first wife immediately after liberation in 1945 , to having lost almost all of his possessions and especially his artwork during the Cultural Revolution, what is amazing in the large body of Suk's post-1978 work is the equanimity, wholeness, and almost ethereal calm that is clearly visible in his art.

In addition to landscape scenes of homeland and nature, Suk's art should duly be noted for the numerous portraits he painted of himself, his wives, and others that reflected his lifework as an educator and pioneer artist in Yanji, China, and Tokyo, Japan. It is because of Suk's legacy and historical importance within the art community in Yanji that his self-portrait and a portrait of his second Japanese wife hang in the office of the art department at Yanbian University today. ${ }^{58}$ Suk is one of the pioneering artists of the Chinese Korean community in Yanji, and though he was a professor of studio art at Yanbian University, he resided in both Yanji and Japan (especially his later years) where Suk eventually spent his last few years with his family before he passed away in $2003 .{ }^{59}$ The public aspect of Suk's portraitures of both human and landscape forms is also another redeeming quality of his art. Suk's work, more than any other There participant, establishes that inherent in landscapes is the personal and collective identities that are formed through the operation of reflective and self-correcting memory, a memory that at once supports the homeland-based sense of a transnational diasporic self, whether that home be Yanji, China, where he made his career, Musan where Suk was born, or Japan where he would later make his final home in an international marriage.

A professional cameraman born in Tashkent, Uzbekistan, presently working in Almaty, Kazakhstan, fourth-generation Russian Korean Viktor Ivanovich 


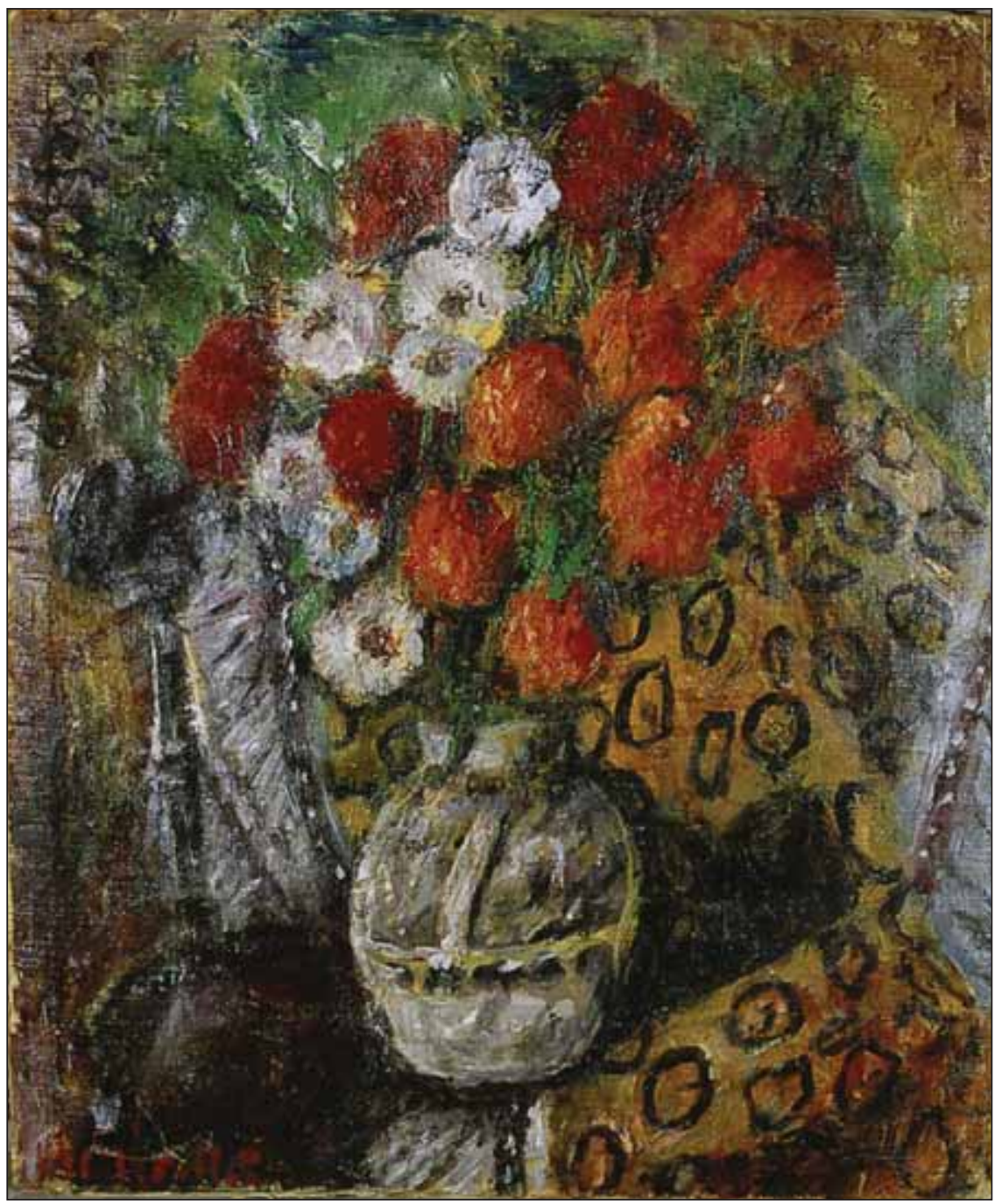

Figure 1. Hee Man Suk, title/date unidentified, oil on canvas, $24 " \times 20$ ". Reproduced by permission from the Gwangju Biennale Foundation.

An presented a melancholic black and white photograph of an older couple in Reminiscences (figure 2). The setting draws a humbly clothed man and woman in front of a dilapidated wood fence , and the rough texture of the couple's rugulose faces - the effect of years of working the land - is lessened with dimmed lighting that creates a nostalgic effect, powerfully emoting the story of Koreans who fled northward from the peninsula and who were forcibly moved from Vladivostok to Tashkent and Almaty. ${ }^{60}$ 


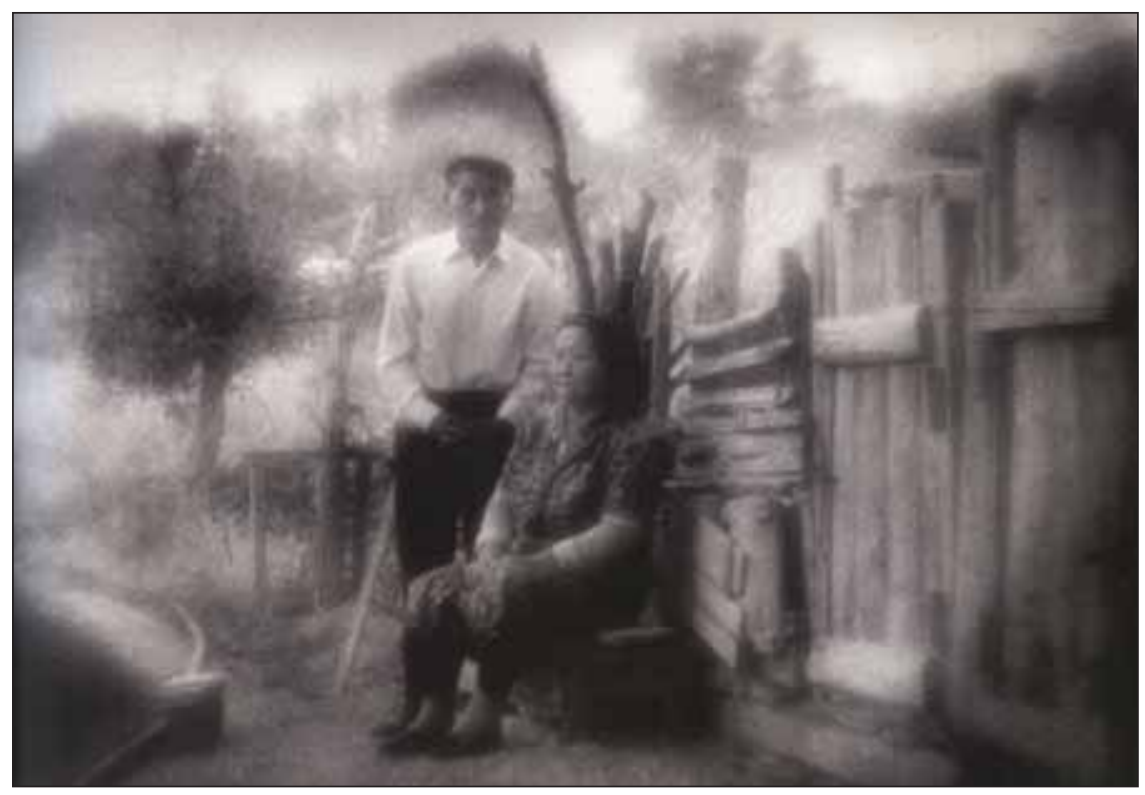

Figure 2. Viktor Ivanovich An, Reminiscences, 1996, photography, 24" × 20". Reproduced by permission from the Gwangju Biennale Foundation.

It is this landscape of arid terrain that South Korean artist Joo Young Kim (Kim Chuyŏng, b. 1965) personally trekked herself in 2002 in an installation/performance piece titled Memory: Koryŏ Saram < Ritual for the Spirit of Rice $>$ (Hoesang: Koryŏ saram <ssal ŭi yŏnghonje>). Her journey replicates the weeks-long train ride that Russian Koreans took in 1937 when Stalin ordered the forced relocation (without compensation) of the Korean minority from the seaport of Vladivostok to an inland area called Ushtobe, located three hours north of Almaty, Kazakhstan. To commemorate the indescribable plight of the dispossessed Russian Koreans, Kim carried out a reformed chesa (ancestral rite) at the grave site of the original deported Koreans in order to pay respect to them and their history of suffering. Part of the chesa was presented at the Kwangju Biennale where she installed the miniature version of mud huts that she imagined Russian Koreans first built upon arrival to the arid region. In addition, she chose to place her installation outside of the exhibition halls, purposefully demonstrating the even further marginalized place of Russian Koreans in the history of overseas Koreans (figure 3).

Joo Young Kim's art practice remembers through ritual what are often dying cultures or forgotten peoples, and she frequently takes long, nomadic, and treacherous journeys to remote areas of the world to carry out her art projects that critique the loss or dying cultures of the neo-liberal capitalist market. Kim's action-centered installation further stands out in the There show for several 

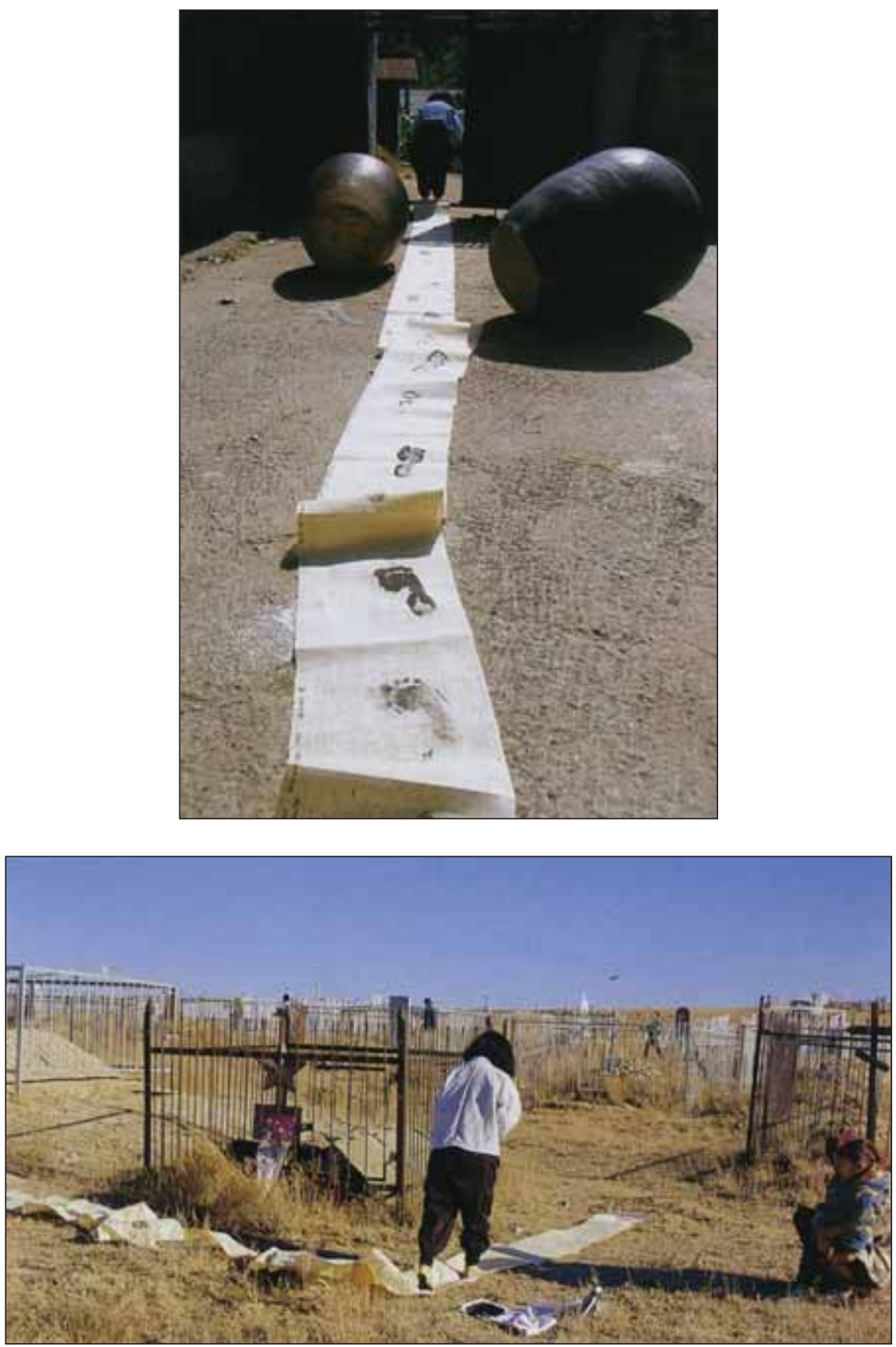

Figure 3. Joo Young Kim, Memory: Koryŏ Saram, <Ritual for the Spirit of Rice >, 2002, performance/installation. Reproduced by permission from the Gwangju Biennale Foundation. 
other reasons. First, she was the sole representative of South Korea, an artist Min included after Sung introduced her and her work on Koreans in Russia. Second, she was also one of three artists who installed performance art pieces of landscapes that, on general view, fit in line with her larger art practice, which is tied to ritualistic performances. Third, even as she spent a considerable fifteen-plus years of time in France as a student and artist in the 1990s and early 2000s, her art piece, Koryŏ saram, parallels nation-centered positions of overseas Koreans within the history of suffering, an important component of the master narrative of the nation. It seems ironic that a young South Korean woman and assistant professor of studio art at Hongik University would retreat into a similar position as Hee Man Suk considering their different backgrounds and time periods in which they were trained as artists. This too, then, is an example of the unevenness of diasporic art.

Y. David Chung's installation Stripmall (figure 4) was one of two installations presented in Project Two: There. A three-walled "intersection" enmeshed with charcoal drawings with three different video sequences embedded in the walls, Chung describes this piece as a formal attempt at depicting his experience of the sense of time and space within a strip mall site.$^{61}$ Chung's repertoire of drawings, animation series, one-man operas, and installations include such titles as Seoul House (drawing/video installation, performance, 1988), Mega Morning Calm (drawing/installation, 1993), Turtle Boat Head (1992, drawing and video installation), which evidently reflect Korean history and culture. Currently associate professor of art and director of the Center for Korean Studies at the University of Michigan, he is represented by Corcoran Gallery in Washington, DC, and has taught or held art residencies at numerous universities and galleries throughout the United States. As a child of a South Korean diplomat father, Chung was born in Bonn, West Germany. After the South Korean coup d'état in 1979, his parents migrated and settled in the United States and ran a grocery store in the DC metropolitan region. This Korean American immigrant story highlighting the tension of Korean/African American relations in urban America throughout the 1980s and 1990s informs much of Chung's earlier multimedia artwork, including his rap operetta titled Seoul House which he wrote, co-directed, and co-produced. Seoul House, received critical acclaim, especially at a time in the United States when Korean-African American relations were tense in the aftermath of the death of Latasha Harlins in March 1991 and the Los Angeles Riots in 1992. Invited by colleges, community centers, and institutions Seoul House was reproduced throughout the country and even made its way to Almaty, Kazahkstan. Seoul House provided an entrée for Chung into the Korean communities of the Central Asian republics, the topic and focus of his most recent documentary, Koryo Saram: The Unreliable People. ${ }^{62}$ This documentary is the fruit of more than a decade of interviewing, filming, and editing. ${ }^{63}$ By viewing a snippet of one artist, Y. David Chung, one can see that an action-centered approach to art, cultural production, and identity construction of contemporary diasporic art are 
equally facilitated by mesolevel frameworks such as community and family that remain pertinent to Chung and his work.

Jin Lee presented an eloquent photograph from a series titled Prairie (Taep'yŏngwŏn, figure 5), a work in four parts that follows the four seasons. Lee's photograph-based art engages landscapes within nature and captures identities as indexical traces of the passage of time. Her Prairie series is particularly befitting discussions of movements, migration, and survival as self-sustaining, perennial plants make up the diverse, self-renewing, and thus healthy plant community. Lee states: "The prairie is such an interesting thing to look at because it's discussed in terms of a true American identity but also as a metaphor for democracy ... it's made up of hundreds of different plants and that's what makes it so healthy unlike farmland which needs constant maintenance because of monoculture which is not a healthy way to grow." The metaphor of the prairie and its own natural survival mechanisms versus the monoculture of the cultivated crops of farmlands is an interesting analogy for diasporic hybrid cultures in relation to the nation-centered singular culture. In Lee's case, her photographic art lens is a witness to the activities of prairie, weeds, and winds, topics of study that specifi-

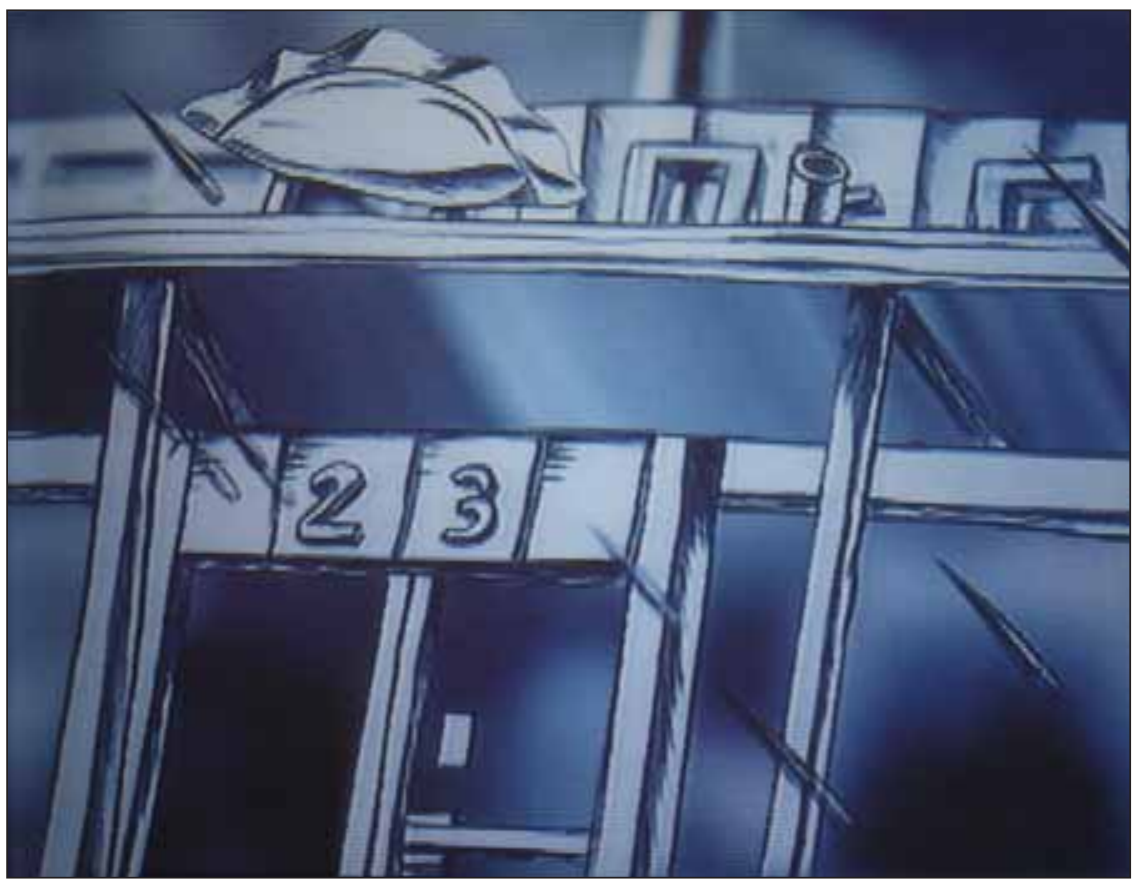

Figure 4. Y. David Chung, Stripmall (detail), 2001, multimedia room installation, dimensions variable. Reproduced by permission from the Gwangju Biennale Foundation. 
cally focus on the unique natural attributes of "Middle America" in her quest for a "sense of place in the world." 64

Y. David Chung and Jin Lee were both present at the Kwangju Symposium as participants of the show, and Chung believes the panel was fascinating and the show an exceptional exhibition with the noted exception that There's spatial layout did not give it the spotlight that it deserved. ${ }^{65}$ In Lee's opinion, the unevenness of the juxtaposition of traditional and contemporary art lent There tremendous appeal.

\section{History, Politics, and Society}

A majority of the artwork from the There exhibition tells a story. It is no mistake that some artists are motivated to tell narratives because the latter provides a sense of meaning in the art-making. Hayden White values the narrative as a "panglobal fact of culture," which is what I believe allows artistic production to resonate with the narrative and narrative form. White claims that the universal, international aspects of narrative are human rather than culture-specific. These collective aspects allow us access into a "metacode, a human universal on the basis of which transcultural messages about the nature of shared reality can be transmitted. ${ }^{\prime 66}$ That is, narrative is a manner of telling characterized by a number of exclusions and subjective conditions, what structuralists ascertain through linguistic criteria — such as the "I" or the third person-to indicate the presence of the storyteller. Whereas structuralists discern difference between narrative and discourse, a form of writing more objective because it does not impose upon the speaker any reference to the narrator, ${ }^{67}$ Hayden White differentiates between a discourse that narrates and a discourse that narrativizes. The former discourse "adopts a perspective of the world and reports it," and the latter discourse "feigns to make the world speak itself and speak itself $a s$ a story. ${ }^{\circ 8}$ It is the latter discourse that narrativizes with which I am dealing in this section on history, culture, and society as experienced and lived through by migrants as diasporic artists.

In Leaving Home (Kohyang ŭl pŏrigo, figure 6), Jun Chae (b. 1926) recounts the histories of Japanese Koreans through symbolic representations that elicit a remembered history; abstract objects piled on top of the head of a solemnfaced woman who is wearing the traditional Korean garb, ch'ima chogori. Using mimetic mechanisms and surrealist abstractions, Chae's piling is constructed to rekindle the image of poor, rural women hoisting heavy goods upon their heads. Fung-sok Ro (b. 1955) presented his earthen ceramic sculpture The Gate (Mun, figure 7). His piece depicts stages of development that Japanese Koreans underwent, emphasizing their ability to overcome each arduous "rite of passage" while residing in Japan. Each stage is marked with a small figurine that narrates the roles that women took on as both laborers and caretakers/mothers. In Ro's depictions of men's roles, their postures - either standing in complete darkness 


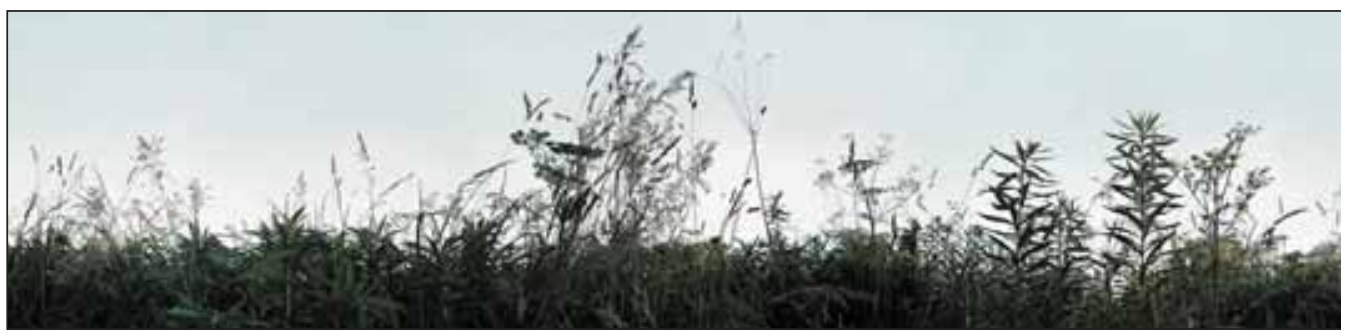

Figure 5. Jin Lee, Prairie, 2000, digital color print, 12" $\times 83$ ". Reproduced by permission from the Gwangju Biennale Foundation.

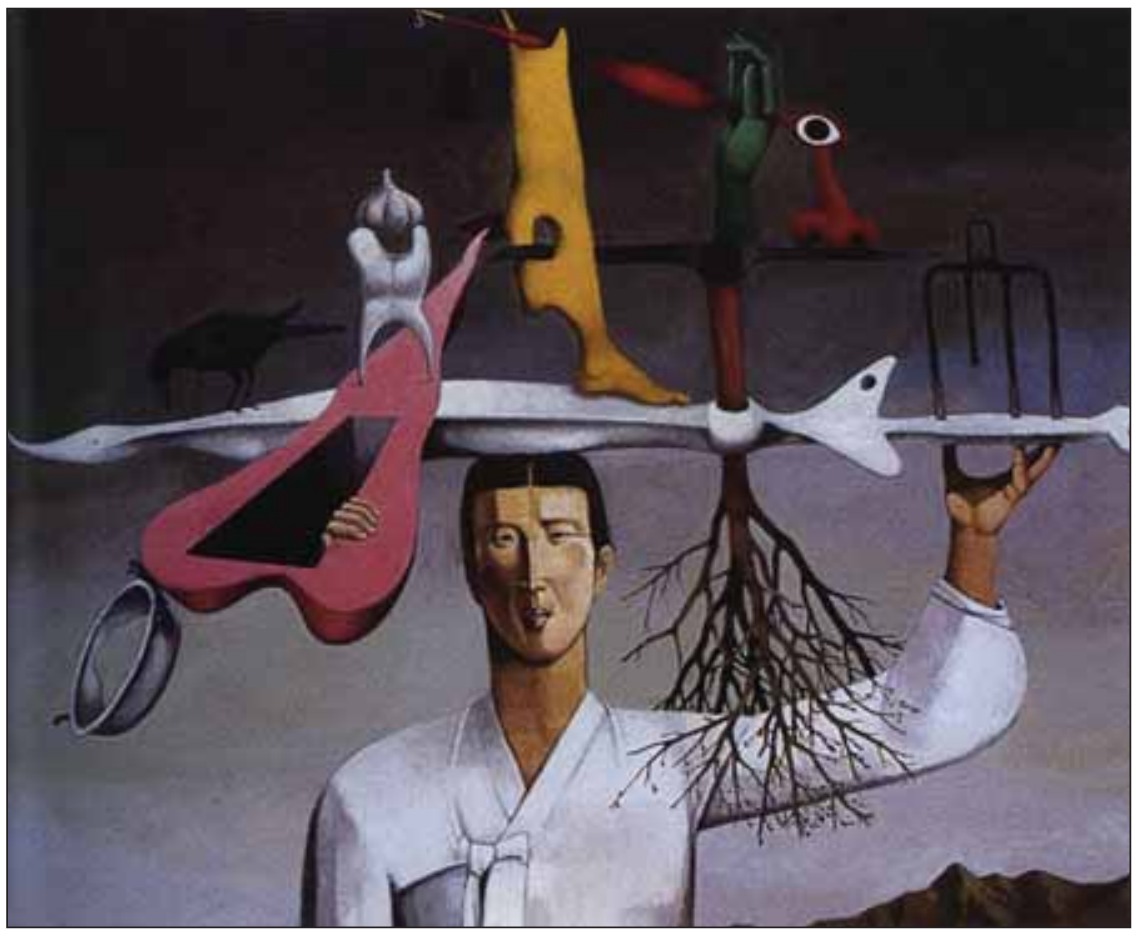

Figure 6. Jun Chae, Leaving Home, 1997, oil on canvas, $91 \mathrm{~cm} \times 117 \mathrm{~cm}$. Reproduced by permission from the Gwangju Biennale Foundation.

or sitting helplessly, curled up with heads placed on their knees - allude to the emasculation felt and disempowerment experienced particularly by Korean Japanese men living in Japan as opposed to Korean men's status within the patriarchal Korean society. 


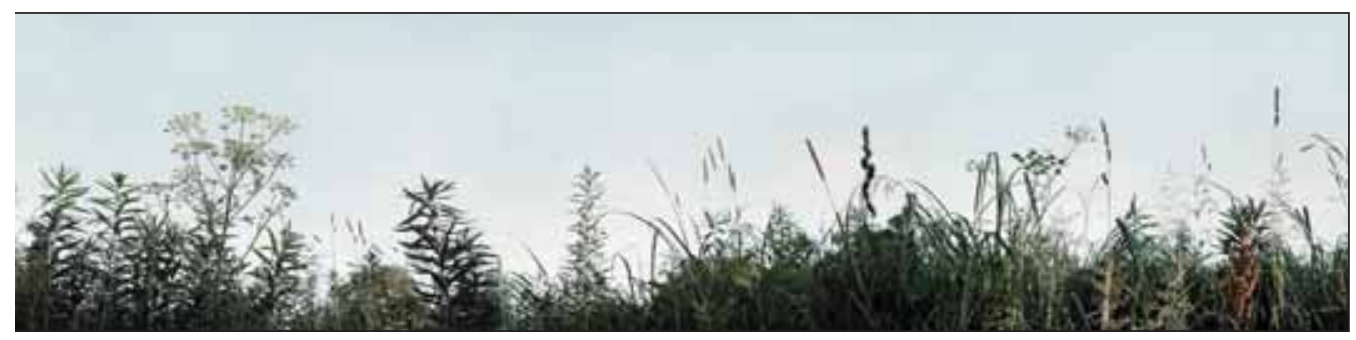

Il Nam Park (b. 1957) and Sung Min Kim (b. 1968) are two Japanese Korean male artists whose work certainly invokes narratives memorialized into Japanese Korean communal identity. At first glance, Park's Gap (Sai, figure 8) evokes a comparison with the abstract minimalism of the painter Barnett Newman. However, this piece is both a depiction of Park's own life-threatening experience during the 1995 Kobe earthquakes and a direct allusion to the aftermath of the Great Kanto Earthquake of 1923 when 6,000 Koreans living in Japan became the targets of attacks by Japanese police. These attacks took place in the span of one week.$^{69}$ Kim's White Shipment (Hǔin chŏkha, figure 9), on the other hand, draws upon the horrific conditions that Koreans endured on boat passages to Japan during the colonial period and the interim period after liberation and before the Korean War (1950-53). The Japanese Koreans' boat experience has left such an indelible mark on their memories that Areum titled its third show in $2004 \mathrm{NeO}-$ Vessel in order to recall their past suffering. Neo-Vessel made its own transnational tour of Kyoto, Tokyo, New York City, and Seoul. Miriam Silverberg begins her M.A. thesis on the massacre of Koreans in 1923 with this quote from "Hell Boats," a popular Korean song of the 1920s that Koreans sang along their journeys. "What have we got to resent / Even our country's been ruined / No wonder our homes lie destroyed / they ship us over and won't let us back / the ferry-boats are all hell-boats." ${ }^{70}$

Areum (Arŭm) is a loosely knit Japanese Korean artists' association whose main mission since its start in 1998 has been and still remains to be the production of triennial art exhibitions, thus far taking place in 1999, 2002, and 2004-5. There are almost three thousand Areum members who reside throughout Japan, yet the organization's commonality is that most of its members were educated in Soren schools-North Korea-affiliated Korean schools (minjok hakkyo) ${ }^{71}$ Yet even a few Japanese, Okinawan, and several Japanese Korean artists not affiliated with Soren are members of Areum.

Areum is yet another example of a mesolevel community network that helps establish interviews for curators and researchers in Japan. Even today, the strong hierarchy among its sempai, or senior members, and cohai, or junior members, allows for accessibility to artists' work, interviews, and other contacts, if called upon. In fact, as head of Areum, Ro was an important contact person for Min during her few days of studio visits and coordination efforts for Project Two 


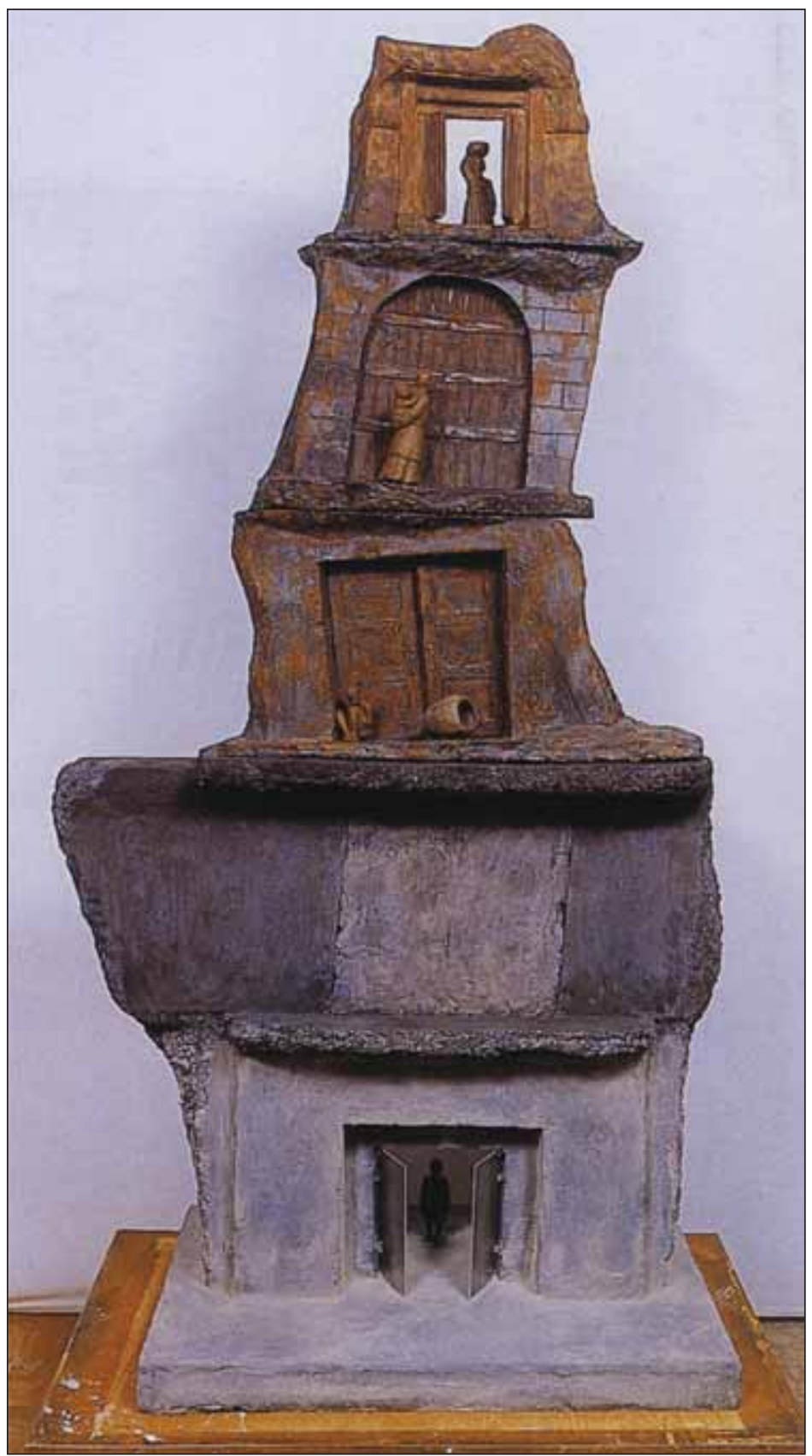

Figure 7. Fung-sok Ro, The Gate, 1994, ceramic sculpture, $150 \mathrm{~cm} \times 69 \mathrm{~cm} \times 48 \mathrm{~cm}$. Reproduced by permission from the Gwangju Biennale Foundation. 


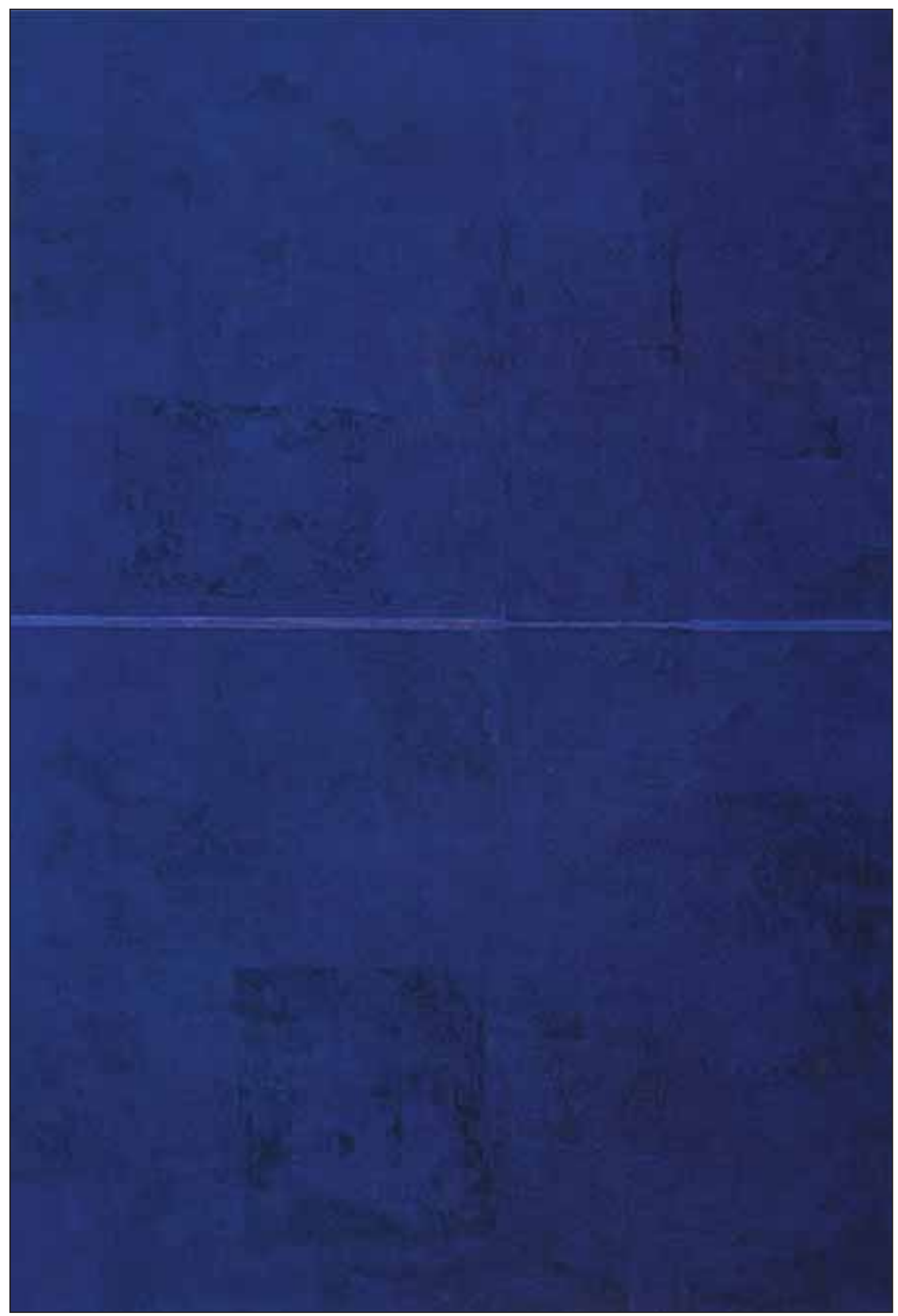

Figure 8. Il Nam Park, Gap, 2001, acrylic and oil on canvas, $194 \mathrm{~cm} \times 30 \mathrm{~cm}$. Reproduced by permission from the Gwangju Biennale Foundation. 


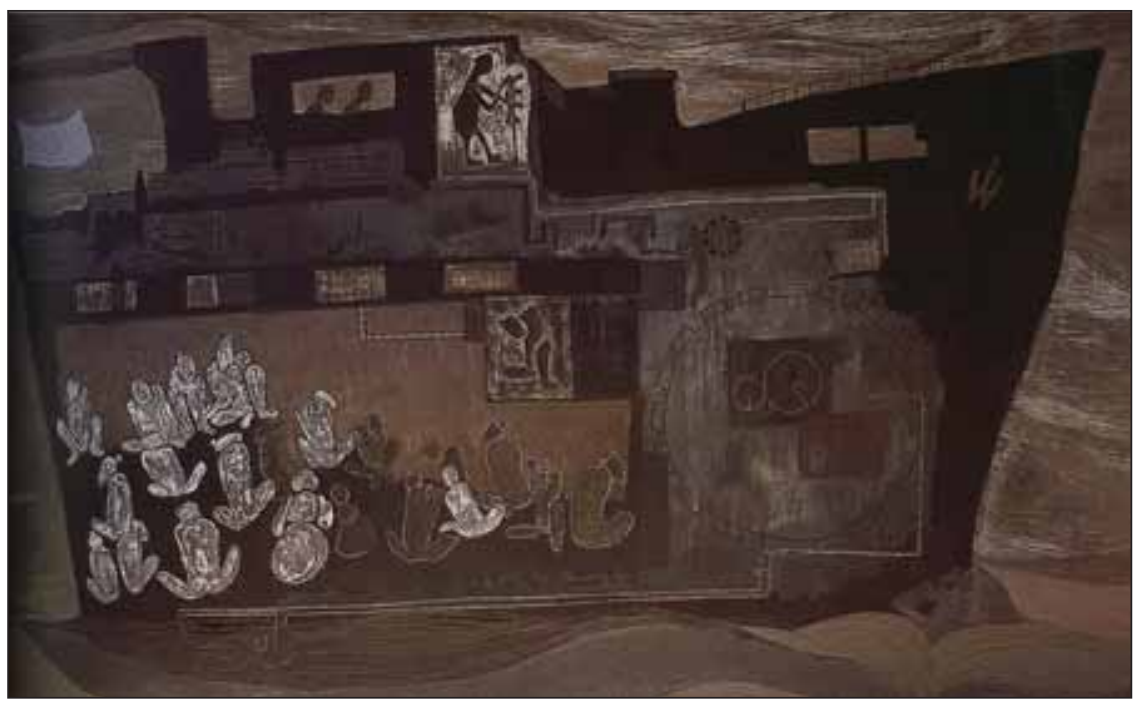

Figure 9. Sung Min Kim, White Shipment, 1999, oil on canvas, $162 \mathrm{~cm} \times 97 \mathrm{~cm}$. Reproduced by permission from the Gwangju Biennale Foundation.

while in Japan. Ro introduced Min to Chinese Korean artists as well. ${ }^{72}$ Chae, Park, and Ro are senior members of Areum, an affiliation that clearly helped secure their invitation to the 2002 Kwangju Biennale. The associational ties and networking involved in diasporic cultural production in Japan provide both stimulus and detriment to the art activities of Japanese Koreans residing there. Many younger and older artists of the field can work and present their artwork together in a group exhibition, addressing the inter-generational tensions and shifts that have created differences between first- and second-generation Japanese Koreans versus the more acclimated third and fourth generations. Yet, the subject that the artists address, as working members and active participants of Areum, uniformly deal with the history, culture, experience, and therefore identity within a more dominant ideological setting. This often means that the narratives of victimhood, suffering, and longing remain underlying themes of visual portrayal. Still, tensions in generational attitudes and opinions come through in the younger artists who were chosen to present There.

What was most interesting in my interview with Areum-affiliated members (five artists) was how easy it was to meet the artists, since Ro facilitated many of the interviews by contacting the artists and setting up the appointments on my behalf, as compared to my normal process of contacting individual artists, going to their studio, often more than once, and carrying out two- to three-hour interview sessions. Moreover, when interviewing the Areum-member artists, I carried out numerous interviews in Korean and in one sitting, both in Tokyo and 
in Osaka. This certainly limited my interaction and relations with the individual artists. However, during the post-interview dinner or coffee, with the younger third and fourth generation Areum members when we spoke in Japanese, much more information was revealed in a subtle context during which time the younger generations' distinct sense of a different subject position vis-à-vis the older first and second generation was revealed. During these interactions, I noticed on the part of the younger artists the sense of belonging to an ethnic Korean nation was much less palpable, if it existed at all. They were much more interested in making art as artists, and not necessarily as Korean or Zainichi artists.

\section{Sexuality and Gender}

The viral male and adorned female bodies found at the center of Chongsuk Kang's Crossing (Kyoch'ajöm, figure 10) and Susan Choi's Orientalism (figure 11) are different conceptions of portraiture than Suk's. ${ }^{73}$ The body has now become the main subject matter, reflecting a difference in gender and generation. The adornment of Choi's (b. 1972) own body flirtatiously interacting with her female counterpart is legible as a subversive, even irreverent manipulation of eighteenth-century, European-orientalist paintings. The European, large-scale paintings evoke heroic, virtuous, and sexualized acts that clearly draw a subject/ object dichotomy. Choi's photograph, however, engages the audience with the large, glossy, photographic print of herself and her model enticing each other to play, seemingly giving both women the right to act and the desire to be acted upon. If Choi's Orientalism addresses issues of race, homoeroticism, sexuality, and gender, then her purposeful use of a European backdrop within the medium of photography invites the question of falsity, fabrication, and desire into the vicinity of the art object.

If we further probe these two young women's work, Choi's ability to proclaim agency through her own bodily insertion into photographic manipulations provides a stark contrast to Chŏngsuk Kang's (b. 1974) larger-than-life-size oil paintings of naked men who seem stuck hanging or slavishly stepping along inscribed walls. Generational differences of Japanese Koreans factor significantly in Kang's bold address of gender and sexuality, one of the first paintings dealing with these issues in Areum circles. The ploy in Kang's work that utilizes dull earth colors to create muscular, powerful male figures captivates me more when I realize she is a third-generation Japanese Korean and an Areum member whose education in national schools (minjok hakkyo) and displacement in Japanese society would direct an art practice quite different from her Korean American counterpart. Her work quietly resists the male-dominated hierarchy of an association such as Areum, and her ability to use oversized male bodies composed in defeated positions is but one indication of the changing attitudes of third- and fourth-generation Japanese Koreans who no longer recognize the telos of return to the "homeland" as an option in their lives. 


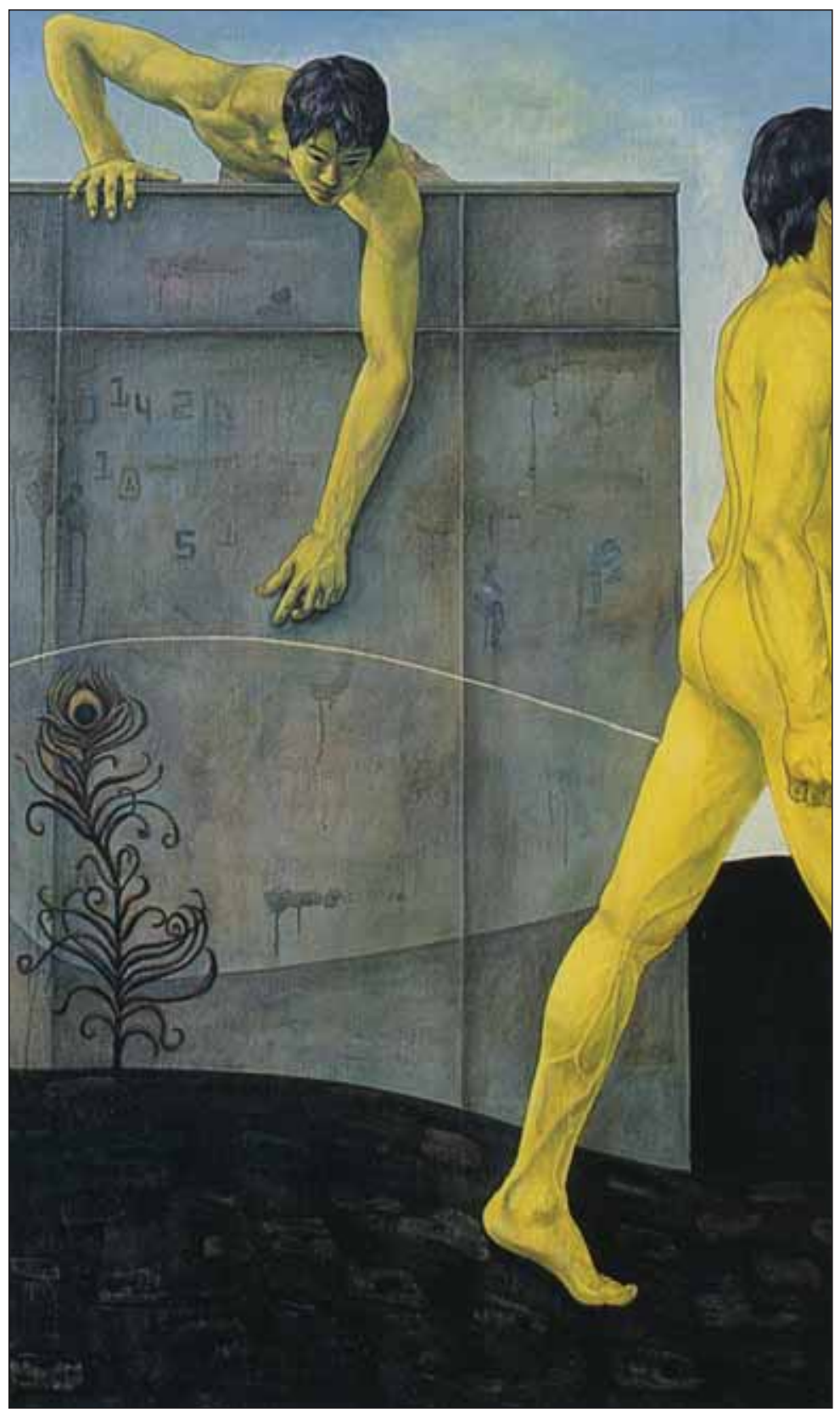

Figure 10. Chŏngsuk Kang, Crossing, 2001, oil on canvas, $162 \mathrm{~cm} \times 97 \mathrm{~cm}$. Reproduced by permission from the Gwangju Biennale Foundation. Note: Catalogue misprinted the artist's name as Yong Suk Kim. 


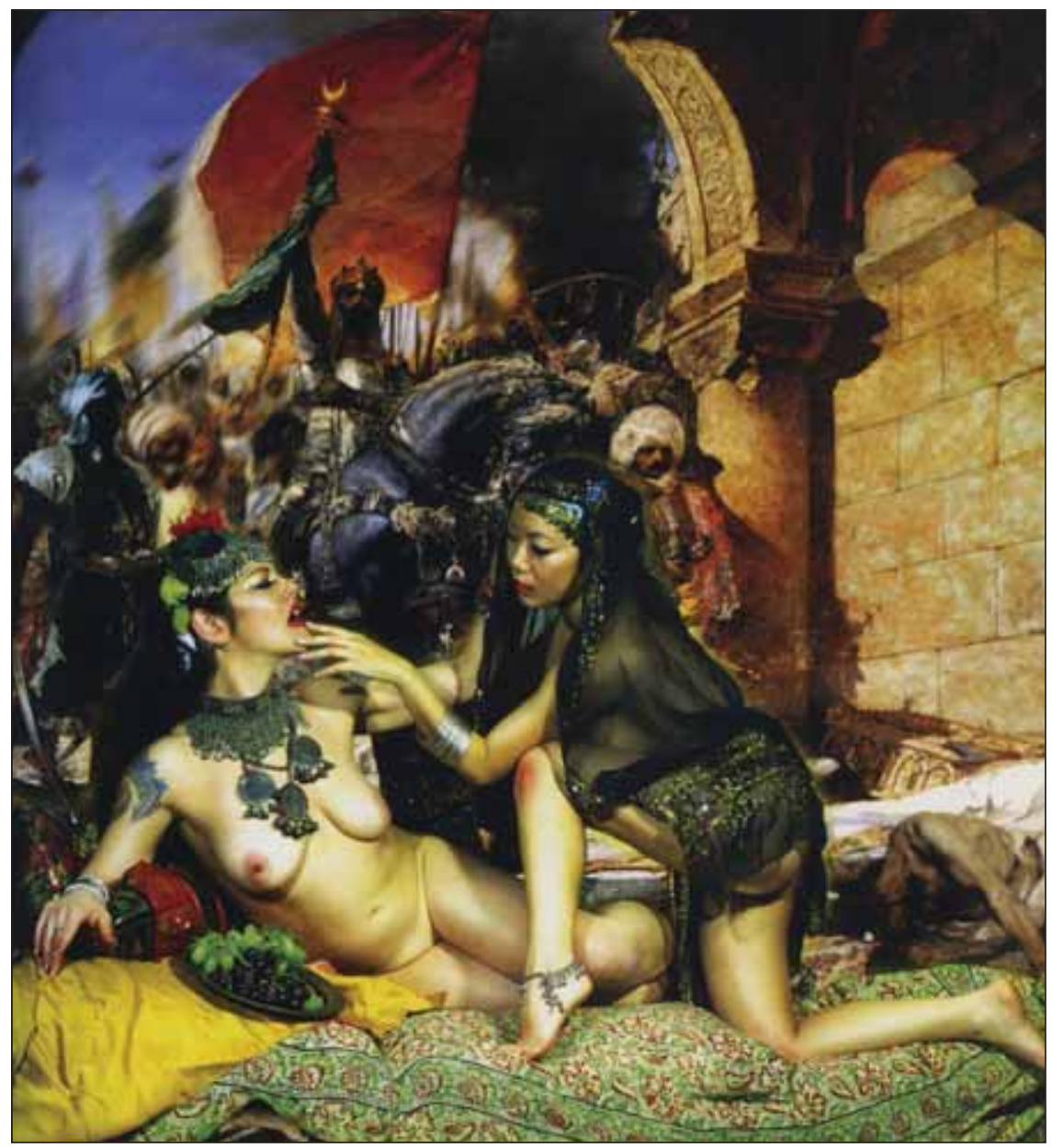

Figure 11. Susan Choi, Orientalism, 2001, photography, $20 " \times 20$ ". Reproduced by permission from the Gwangju Biennale Foundation.

The Japanese, Chinese, and Russian Korean artists' narratives are based upon personal and family experience and their historical memory of that experience. On the whole, their stories support the prevalent mode that South Korean migration studies also underline: that of the plight and suffering of Korean migrants who left at the turn of the century and during the colonial period. One distinguishing feature of an oral historian's work is that it involves recalling past events by engaging memory. In a significant number of my interviews, artists certainly did recall the past in order to produce their artwork, and in a few cases, their art practice is entirely based upon memorializing. How do 
we assess the material truth and significance of memory? Does a distinction between historical memory and collective memories help articulate memory's function in diasporic art?

\section{Abstraction}

In juxtaposition to those narratives of struggle and the history of suffering that Japanese Korean artists Chae, Park, Kim, and Ro interpreted, U.S.-based artists appeal to narratives based not upon real experiences but fantasy and myth. The L.A.-based artist Wonju Lim engages in historical memories of Greek myths and ancient folklore in dense, excessive, architectural installations. Her work captures complex compositions made from Plexiglas, acrylic, polyester film, and foam-materials that reflect, absorb, and refract light, emitting images upon the walls of the installation. The piece she presented in 2002 at Kwangju, Elysian Field (figure 12), is named after the place reserved for the souls of the heroic and virtuous in Greek mythology. The installation is part of a series of works including Terrace 49, Baroque Palaces, or Schlemann's Troy, examples of installations that contemplate the constructed myths stemming from memories of places.

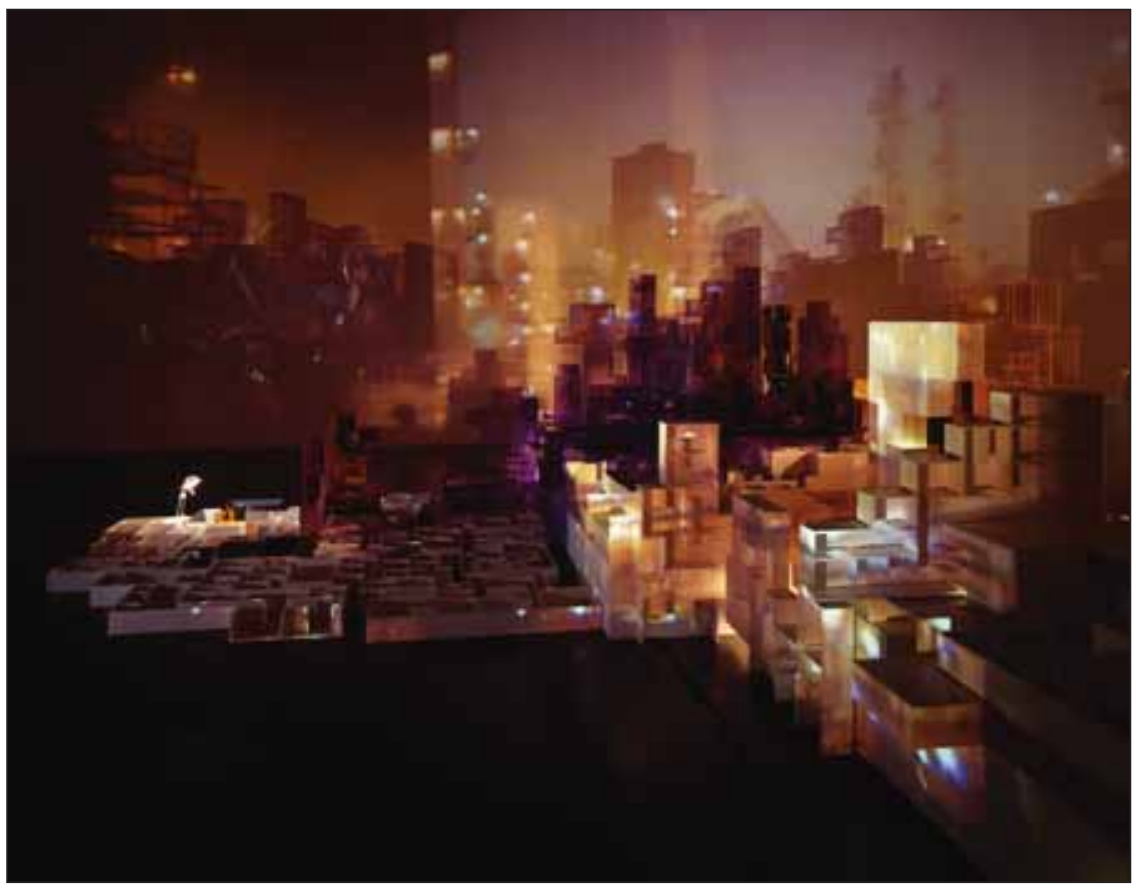

Figure 12. Wonju Lim, Elysian Field, 2001, installation, dimensions variable, Reproduced by permission from the Gwangju Biennale Foundation. Photograph by Fredrik Nilsen. 
Lim is attracted to stories of myths that beckon the past, but she purposefully "rips apart" any coherence of a story with a beginning, middle, and end within her three-dimensional representations of the stories. ${ }^{74}$ In this process, any original points of reference become indexical traces that then allude back to the story only as moments of remembrance - still shots of Wilmington California, Highland Park sunsets and sunrises, factories in postindustrial Berlin, and Hollywood palm trees. In the end, Lim's installation does not encumber the viewer with the weight of history, and the three dimensionality of her work, presented in compartmentalized landscapes, befits her artistic strategies. In this process, she creates seamless sets of well-sold and well-represented artwork, compared to other artists in the exhibition. She is one of a handful of artists who has multiple gallery representations in the United States and Europe.

Fantasy is foremost on the minds of Jennifer Moon's superheroes. Moon's art practice is conceptual and performative. She enacts multiple subjectivities through her body in everyday life, as the business entrepreneur Deirdre Swan, the sex goddess Electra, and the superhero she was training to become on the installation gym set at the Kwangju exhibition site. She first began training to become a superhero as an art student at UCLA and then expanded this idea into a regimented art practice. Moon literally enacts the various identities she assumed in projects to become a publicly recognized superhero, icon, pop star, or sports star, and she will embody these imagined heroes for years in time, literally, in order to create what she calls a "third communal entity." 75

Mark Roskill and David Carrier's treatise on truth and falsehood in visual images shows a more disputatious relationship between objects and their environment and may help make sense of Moon's years-long dedication to her fictitious superheroes. They write: "Falsehood, fabrication, guile, and deceit, and the impossibility in modern aesthetic tradition come into use to indict the alienation of a modernizing world and deterioration of the human condition that spreads to encompass the world in its everyday activities." ${ }^{\prime 76}$ They come to the conclusions in their analysis of Pieter Bruegel's Netherlandish Proverbs of 1559 that the increasing alienation of humans from their world manifests visually with the "loss of center" in nineteenth- and twentieth-century art. ${ }^{77}$ In effect, the changes of modern life signify an epistemological shift in the interpretive framework of visual artwork, such that the "things that artists do, and always did, come to carry negative connotations, in social and political terms." With changes stemming from modernity, falsehood helps to evoke not only the "degree to which human fantasy is capable of permeating from thought into actuality, but [also] the fabrication of an 'impossibility' that directly embodies the artist's sense of what is out of joint in the world." 78 Though in contemporary times, Moon's desire to work in the realm of fantasy and fabrication is a performative practice invoking all that is "out of joint" with our world (figure 13).

Susan Choi, Chŏngsuk Kang, Wonju Lim, and Jennifer Moon render narrations - real, mythical and impossible — into affective visual artwork. They 


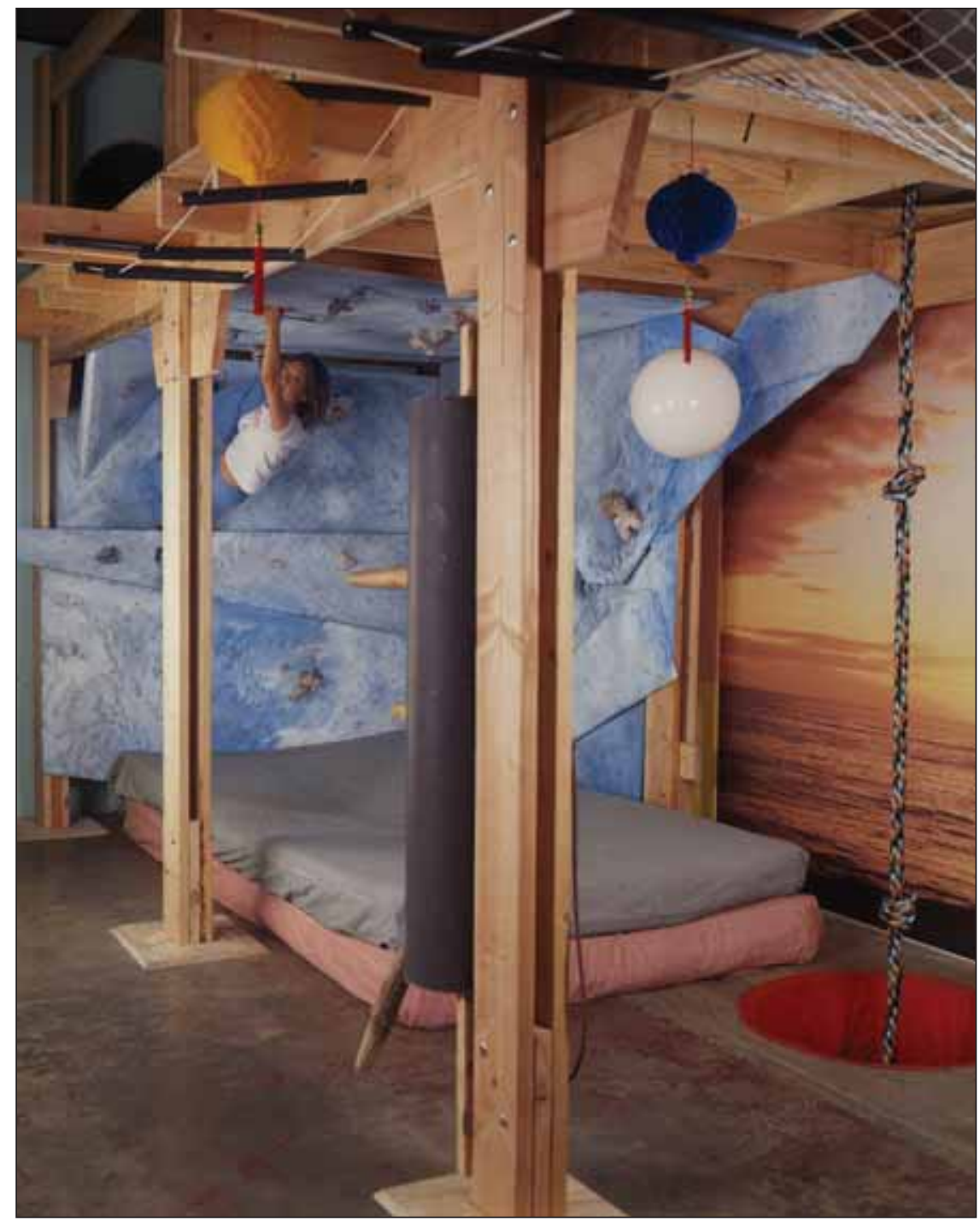

Figure 13. Jennifer Moon, Facility, 2000, installation, dimensions variable. Reproduced by permission from the Gwangju Biennale Foundation.

purposely chose subject matter recounting events that prove significant, not necessarily because they happened, but because they were remembered. Most importantly, the content of their remembered events found their way into a visualized form that became fragments of There. But what about the untold stories? 
Curating a show on Korean diaspora proved difficult, and the absence of several artists from the analysis is yet another point of tension mounted between artists and the show, or artists and the curator. Although I have interviewed fourteen artists, curators, and others involved in the production of There, artists' schedule conflicts and far-away residences prevented interviews with another ten. Hee Man Suk passed away in 2003. The other Chinese Korean artist was working in Beijing while I was in Yanji. The limitations of a dissertation budget prevented my going to São Paulo and Almaty to interview the two artists from Brazil and Kazakhstan; and still, another failed to show up twice for interviews. Lina Kim is an artist from the São Paulo region who has left that region and currently is represented by Galerie Fahneman in Berlin where she has been working and residing since the mid-2000s. Since 2006, she has closely collaborated with Michael Wesley in such settings as the Ninth Havana Biennale, Haus de Kunst of Munich, Palazzo Cavour in Torino, and Galerie Soto Blanca in Madrid. Indeed, their initial collaboration titled Arquivo Brasilia has recently been published into an English-language book titled Archive Utopia: Project Brasilia in 2010. ${ }^{79}$

Finally, two artists flatly rejected my requests for studio visits via e-mail correspondence writing that they no longer wanted any ties to the "diaspora show." I cannot assume why David Korty and Hee Chang Yoon did not want to be interviewed, but Korty's painting, Untitled (figure 14) and Yoon's That Which Is There (Kŏgi e innŭn kŏt, figure 15) were both landscapes and these artists would have added further to the social dimensions of landscapes and the regime of art that places equality of cultural constructions in action. Korty is the only biracial artist from the entire collection and Yoon the only non-Areum Japanese Korean artist. If Korty paints striking photo-quality landscapes of the same Los Angeles cityscapes that Lim captures within architectural compilations, then Yoon's philosophical ceramic sculpture pieces provide meditative relief from the sociopolitical, narrative-driven sculptures by Areum leader Ro. Ro and Yoon both came of age in the same generation as Japanese Korean artists, and if Yoon had responded positively to my request, the comparison may have been illuminating.

As for Min, she dealt with the uneven artistic practices in disparate locales by using flexible criteria of what she labeled a "visual cultural approach," rather than relying upon the "prevailing criteria to find 'cutting edge' work." ${ }^{80}$ Whereas Min never explicitly explains what her "flexible criteria" are, she does state that such an approach fashioned "a truly heterogeneous global art reality of artists" who are working in both "contemporary post-modern mode and in traditional or modern genres." ${ }^{81}$ One curatorial issue was how to justify her showing the admixture of a contemporary Wonju Lim and the traditional landscapes and portraitures of Hee Man Suk from Yanji and Japan in the same arts exhibition without critical backlash that would reduce the work to anachronistic or ethnic art. From a curatorial standpoint, there are two dominant bookends that Min herself critiques; on the one end, her own U.S.-based biases and on the other, the funding from and showing in South Korea for a predominantly South Korean and espe- 


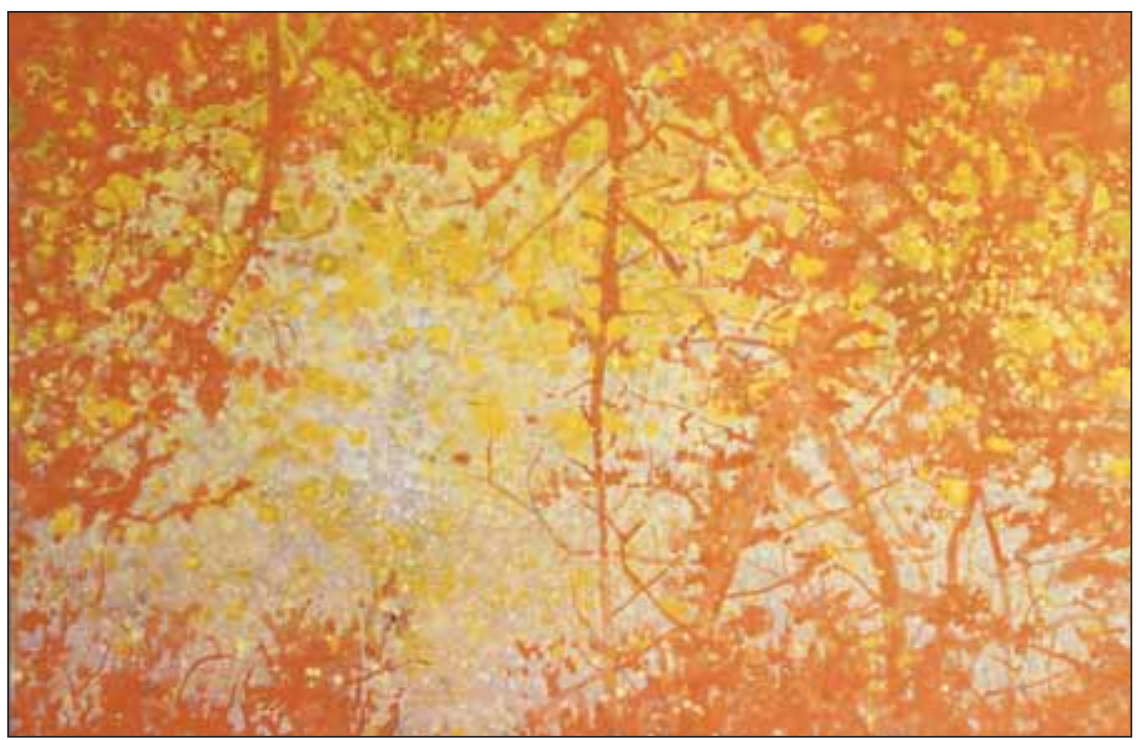

Figure 14. David Korty, Untitled, 2000, acrylic on panel, 33" $\times 48$ ". Reproduced by permission from the Gwangju Biennale Foundation.

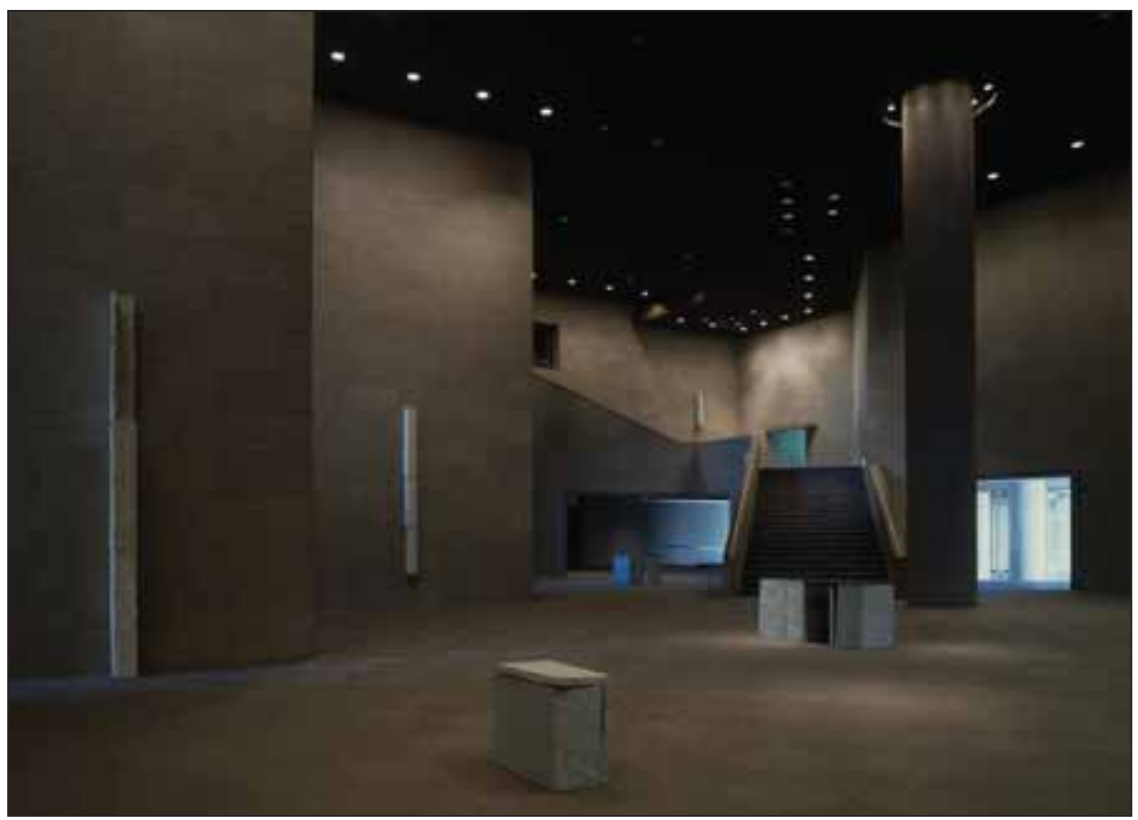

Figure 15. Hee Chang Yoon, installation view of That Which Is There, 1994, ceramic sculpture. Reproduced by permission from the Gwangju Biennale Foundation. 
cially Kwangju audience. At this point, it is crucial that we recognize that the five There sites Min highlights did not allow for an open position. In fact, it seems as if there are two opposing fixed vantage points. Even if there existed a scale of diasporic identities, they would be confronted with the fixity of the South Korean nationalistic perspective on the one hand and the Western or U.S.-privileged perspective, that relies upon the logic of late-capital that in its "multicultural aesthetic reading" still desires highly stylized, marketable objects, on the other. ${ }^{82}$

\section{CONCLUSION}

Within a diasporic framework, the spatial representation of five far-flung locations of Korean diasporic artists expanded the experience and expression of the collection of artwork presented at There. Do artists and artistic intervention challenge the national identity, culture, and consciousness that are the crucial components of national history? The geo-cultural corpus of the biennale structure critically develops the idea of diasporic art and proves that it can exist alongside a national frame. Discovering the artists through the 2002 Kwangju Biennale There exhibition clarified the powers of diaspora that lie in intercultural associations collected in a biennale platform, and help us to imagine alternative means toward understanding minor histories and differing identities. Yet when sites of the Korean diaspora are explored in the specific intercultural activities of the Kwangju Biennale, even as diasporic art exists alongside national frames, an expansive diasporic consciousness does not necessarily overcome Korean national history and national consciousness, thus I call There a provisional emancipation from dominant hierarchies constituted (within its own components) by cultural equality.

The body of work I offer through the themes of landscape, history, culture, society, sexuality and gender, and abstraction lays claim to the unruly complexity of artists' senses of self and to the radical indeterminate nature of an actioncentered approach to art. In this claim, I offer diasporic art as a category that can exist alongside national discourse of grand narratives and embraces equally the twenty-four artists who embody a paradox of diasporic art in the case of the 2002 Kwangju Biennial's There project. At the same time, diasporic art expands the space of Korean identity construction(s) by incorporating the creative expression of artists from different generations and multiple diasporic host communities/ countries, all underlined by vastly differing art practices.

Wonju Lim, Jennifer Moon, Chŏngsuk Kim, Lina Kim, Sangwon Kim, and others do not categorize themselves as "Korean," "feminist," "ethnic," or "Asian" artists. Their art practices challenge any identity-bound narratives that may limit their art practice. They equally resist nation-bound narratives and discourses that may otherwise make their entrée into and activities in the larger art market and art world difficult. Hee Man Suk, Il Nam Pak, Fung-sok Ro, Viktor Ivanovich 
An, Jun Chae, and Joo-Young Kim reflect upon their connection to homeland in the political and cultural terrains of their paintings, photographs, and installations. The fact that both types of artists were chosen to show their art in this exhibition is undeniably a reflection of the two main curators, Yong Soon Min and Wang-kyung Sung, and the curators' relationship to the Korean nation and cultural identity. Linda Hutcheon underlines this paradox as what characterizes postmodern art "which works to subvert dominant discourses, but is dependent upon those same discourses for its very existence: the "already-said." ${ }^{83}$

The idea of paradoxes that undermine master narratives at the same time as they support them is one of several contradictions Hutcheon underlines as paradoxes of postmodernism. The challenges to historical narratives as "facts" or "truths" are not new ones but have firm roots in the modern. The implications for examining paradoxes of the margins, of those excluded from the center, are what I explore in diasporic art, art making, cultural production, and the radical indeterminacy that interrogates sameness, oneness, homogeneity, and unity at the same time that it makes room for difference, heterogeneity, hybridity, and the provisional. ${ }^{84}$

\section{NOTES}

1. Gabriel Sheffer, "A New Field of Study: Modern Diasporas in International Politics," 3 .

2. Naoki Sakai, "Introduction: Nationality and the Politics of the 'Mother Tongue,", 1-38. I thank Christopher P. Hanscom for introducing me to this article.

3. Dirk Hoerder, Cultures in Contact: World Migrations in the Second Millennium, $16-21$.

4. Images of prototype visualizations for this article are provided on the website for University of California, San Diego's Software Studies Initiative led by Lev Manovich. It provides cursory ideas of what forms visualizations from the There dataset could yield. ArtDiaspora.viz - Korean Modern Art Diaspora in a Global World, software studies initiative, http://lab.softwarestudies.com/2008/05/artdiasporaviz-korean-modern-art.html (accessed September 10, 2008).

5. I am contextualizing overseas Koreans as depicted in a master narrative of the nation and thus translating overseas Koreans as chaeoe tongp'o, but on-going debates about the socio-political history of terminology continue. For a lengthy discussion on the problems of translating the term for overseas Koreans, please see the following: Hyun Ok Park, "Segyehwa: Globalization and Nationalism in Korea"; Kwŏn Hyŏkt'ae, "Chae-Il Chosŏnin wa Han'guk sahoe; and Son Hŭiju, "Haeoe tongp'o rŭl kyŏnyanghan ch'oguk kajŏk chŏngch'aek, 364-93.

6. Kim Sangho, "2000 Kwangju biennalle ŭi chiyŏk kyŏngje p'agŭp hyogwa," 1-16; Kim Yŏngho, “Tong Asia ŭi munhwa chŏngch'esŏng kwa Kwangju biennalle," 145-73; Yi Hŭich'an, "Megaibent’ŭ ŭi chiyŏk kyŏngje hyogwa ch'ujŏng pangbŏp yŏn'gu," 155-76; Paek Chisuk, "Kwangju biennalle kwallamgi," 207-18; Pak Ch'angyŏng, "Kwangju biennalle wa pyŏnyŏk," 78-83; Pak Sijong, "Kwangju biennalle, tasi t'aeŏnanda," 194-97; Yu Yŏng-guk, "Kwangju biennalle wa chiyŏk kyŏngje,” 33-39. 
7. John B. Duncan, "Protonationalism in Premodern Korea," 198-221.

8. Benedict Anderson's study of nationalism shows how such a long and august history is a necessary component of nation-state building. Benedict Anderson, Imagined Communities.

9. Yi Pyŏngdo, "Chosŏn minjok ŭi tanilsŏng," 8-15.

10. Keith Pratt and Richard Rutt, Korea: A Historical and Cultural Dictionary, 458. Don Baker describes Taejonggyo as a revival religion of ancient Korea that celebrates as its founder Tan'gun and its believers insist on a Trinitarian God of Hwanŭng, Hwanin, and Tan'gun. Don Baker, "Introduction," in Religions of Korea in Practice, 29.

11. Kim Kyohŏn, Sindan silgi.

12. Pai and Tangherlini read the term paedal as a racialized colonial category within a discourse of Koreanness (Han'gukillon), but I am unsure exactly how this term was used to categorize Koreans as a "chosen" people "saved from Japanese efforts at eradication and assimilation by the Tan'gun spirit of independence" since there are no sources citing this discursive context. Hyung Il Pai and Timothy R. Tangherlini, eds., Nationalism and the Construction of Korean Identity, 4.

13. Scholars of Sin Ch'aeho describe that before Sin, writings of Korean history lacked a true historical consciousness. Henry H. Em, "Minjok as a Modern and Democratic Construct: Sin Ch'aeho's Historiography," 336-61; Hyung Il Pai and Timothy R. Tangherlini, eds., Nationalism and the Construction of Korean Identity; and Andre Schmid, Korea between Empires, 1895-1919.

14. Yi Kwanggyu, Segye ŭi Hanminjok, Preface. The quote comes from the first page of the first volume, but there is no pagination until the table of contents appears on page 15.

15. Yun Pyŏnguk, Nara pakkesŏ nara ch'ajanne: Miju Hanin tongnip undongsa ŭi chaeinsik [Getting Korea back outside that you lost inside: Rethinking the Korean independence movement in America]. I present the awkward translation of the Korean title as it appears on the cover of the book, but I would have translated "Nara pakkesŏ nara ch'ajanne" as "Finding Nation outside the Nation."

16. Wang-kyung Sung, interview by Hijoo Son, Seoul, September 20, 2006.

17. Ibid.

18. Min received her B.A. from Monterey College in 1975, M.A. in 1977, and M.F.A. in 1979, both from the University of California, Berkeley.

19. Elaine H. Kim, Margo Machida, and Sharon Mizota, eds., Fresh Talk, Daring Gazes. In addition to the success of Changrae Lee in the U.S. literary world, the recent best-selling authors Min Jin Lee, Free Food for Millionaires and Janice Y. K. Lee, The Piano Teacher, also deal with Korean American or Asian American themes. Korean Americans are recognized in mainstream American cultural worlds such as chefs Cory Lee of the renowned French Laundry in Yountville, California; fusion food entrepreneur David Chang of Momofuku (with restaurants in New York City, Sydney, and Toronto); Kogi Taco Truck founders Ray Choi and Alice Shin in Los Angeles; Korean American fashion designers Doori, Eunice Kim, Richard Chai, or Kyung Lee of Albertine; curators Eungie Joo and Doryun Chong of the New Museum and the New York Museum of Modern Art (MOMA), respectively; and Hollywood actors/comedians Margaret Cho, Sandra $\mathrm{Oh}$, and Leonardo Nam.

20. David Joselit, "Ring of Fire," 87.

21. Kobena Mercer, "Diaspora Culture and the Dialogic Imagination," 43. 
22. Yong Soon Min, interview by Hijoo Son, Los Angeles, California, July 8, 2002.

23. Yong Soon Min, "Certain Latitudes," 58.

24. Moira Roth, "Traveling Companions/Fractured Worlds," 82.

25. I am grateful and indebted to Dr. Chin for allowing me access to all interview tapes in her possession from these research trips. Since Project Two: There received so little attention discursively and in the media, and especially since I was unable to attend as I was a graduate student at the time who thought she was writing a dissertation on Japanese migration policies during the colonial period, I paid particular attention to the research team's efforts after changing my dissertation topic. I attempted to contact the other two research team members, but was unable to meet with either Yoon Cho (though we had a brief phone conversation) or Miyoung Kim who has "dropped off the face of the earth" after the 2002 show according to Min.

26. Yun Pŏmmo, "Isan ŭi ttang, isandoen chŏnsi kihoek," 78.

27. Ibid.

28. Interviews by Hijoo Son include Chan-kyong Park, May 19, 2005; Suknam Yun, June 24, 2005; Duck-hyun Cho, September 9, 2002; kimsooja, May 25, 2007; Ikjoong Kang, August 25, 2005; Ok-sang Kim, June 21, 2005; Oksang Lim, September 4, 2005; Yong-suk Park, August 29, 2007; and Jun Lee, October 8, 2011.

29. Paul Yi, interview by Hijoo Son, Los Angeles, California, June 15, 2002.

30. Doryun Chong, interview by Hijoo Son, Berkeley, California, July 15, 2002.

31. The fact of the symposium's cancelation was well known to all those involved in the panel discussion component of There's production including not only Min and Sung but also other academics, artists, critics, and curators who had planned on attending the panel.

32. There's budget was officially $\$ 22,000$. Extra costs included the catalogue publication and shipping of art for which Min recalls receiving $\$ 5,000$. After the symposium's cancelation and the complaints from There organizers including Min and others, the artistic director provided additional "private funds" and the intended symposium was carried out with an additional $\$ 10,000$. Yong Soon Min, interview and email exchange with Hijoo Son, August 22, 2005, and July 29, 2011.

33. Some of the press coverage Han Diaspora received included the daily newspapers Munhwa ilbo, Chosŏn ilbo, Chungang ilbo, Han'guk ilbo, Kungmin ilbo, and Han'gyŏre sinmun, as well as magazines and radio/television broadcasts, for example, Vogue Korea, In Magazine, Hangyore 21, Lady Kyonghyang, SBS Morning Show, and Christian Radio Broadcast. The other co-founder of Han Diaspora was artist and activist Nathalie Lemoine, also known as Cho Mihee.

34. Sŏ Kyŏngsik, Nanmin kwa kungmin sai: Chae-Il Chosŏnin Sŏ Kyŏngsik ŭi sayu wa sŏngch'al; Yun Injin, K'orian tiasŭp'ora, chaeoe Hanin ŭi iju, chŏgŭng, chŏngch'esŏng.

35. Yong Soon Min, interview by Hijoo Son, Los Angeles, California, August 22, 2002.

36. Tae Shin Chung, "Making History in the Trench City of Kwangju"; Jae-eui Lee, Kwangju Diary; and Gi-Wook Shin and Kyung Moon Hwang, Contentious Kwangju.

37. Gi-Wook Shin and Kyung Moon Hwang, Contentious Kwangju, 26.

38. Norman G. Finkelstein, The Holocaust Industry, 3.

39. Kim Manhŭm, Han'guk chŏngch'i ŭi chae insik, 45-46. See also, Haeran Shin, "Cultural Festivals and Regional Identities in South Korea," 619.

40. Ibid., 623.

41. Ho-Ki Kim and Jongil Park, "Renegade Region or the Center of New Nation." 
42. Kim Sangho, “2000 Kwangju piennalle ŭi chiyŏkkyŏngche p'agŭp,” 1-16.

43. Kim Manhŭm, Han'guk chŏngch'i üi chae insik, 277; Haeran Shin, "Cultural Festivals and Regional Identities in South Korea, 621.

44. Samuel Kim, "Korea's Globalization Drive," 83-84.

45. Young Sam Kim, Korea's Quest for Reform and Globalization, 273.

46. Kyŏng-soo Chun, "Policy for Five Million Overseas Koreans," 59-65.

47. The overall theme title $P_{-}$A_U_S_E was stylized as a reference to twentieth-century language poetry.

48. Wang-kyung Sung, interview by Hijoo Son, Seoul, September 20, 2006.

49. Art historians have addressed modern art and its social implications or the impossibility of extricating artwork from its social and political worlds. But most focus upon the history of social realism and Marxist intellectual tradition to reflect upon the social issues involved in art history's object-based analysis and critique. Meyer Shapiro first gave a speech on this topic to the First American Congress of New York in 1936 and published an essay in Social Realism-Art as a Weapon: Critical Studies in American Art; cited in Meyer Shapiro, "The Social Bases of Art," in Art in Theory 1900-1990, 508.

50. Jacques Rancière, The Politics of Aesthetics: the Distribution of the Sensible, 83, 86.

51. Ibid., 52-54.

52. Alfred Gell, Art and Agency: An Anthropological Theory, 6.

53. Casting Diaspora: 2002 Kwangu Biennial, There, http://dev.cdh.ucla.edu/ cdiaspora/ (accessed January 10, 2008). This website provides access to all of the art images discussed. It is organized according to the characteristics of the artist and artwork (artist, title of work, form of work, date of work, place of creation, place of birth, date of birth, education, gallery representation, websites, other exhibition venues, place of interview/date of interview).

54. Please see: ArtDiaspora.viz-Korean Modern Art Diaspora in a Global World, software studies initiative, http://www.lab.softwarestudies.com/2008/05/artdiasporaviz -korean-modern-art.html.

55. Yong Soon Min, "Certain Latitudes."

56. The Tokyo Fine Arts School (Tōkyō Bijutsu Gakkō) and Tokyo Music School (Tōkyō Ongaku Gakkō) were both founded in 1887 and merged in 1949 to create the Tokyo National University of Fine Arts and Music (Tōkyō Geijutsu Daigaku), which today is called Tokyo University of the Arts.

57. Yi Sŭngnyŏng, "Sŏk Hŭiman ŭi saengoe wa chakp'um segye e kwanhan yŏn'gu."

58. I discovered this upon entering into the administration offices of Yanbian University's Studio Arts Department on April 21, 2007.

59. Chŏn Chŏnho, "Chungguk Yŏnbyŏn Chosŏnjok misul ŭi hyŏnhwang," 82-83.

60. Hae-kyung Um, "Community, Identity, and Performing Arts," 43-60.

61. Y. David Chung, interview by Hijoo Son, Los Angeles, California, May 15, 2008. Chung states that he arrived in Kwangju after the opening and thus had sent specific set-up instructions for his installation, which was protocol at other museums where he also showed this particular piece. He noticed that the three video projectors were disseminating the same video at the same time, which was not the piece he had intended for the show. For a better image of the installation, please visit his website: Y. David Chung, http://davidchung.com (accessed January 11, 2007). 
62. For more information, see: Koryŏ Saram: The Unreliable People, http://www .koryosaram.net (accessed July 28, 2011).

63. Y. David Chung, interview with Hijoo Son, Los Angeles, California, May 15, 2008.

64. Jin Lee, interview by Hijoo Son, Los Angeles, California, July 5, 2007.

65. Y. David Chung, interview by Hijoo Son, Los Angeles, California, May 15, 2008.

66. Hayden White, "The Value of Narrativity in the Representation of Real Life," $1-23$.

67. The relationship between "discourse" and "narrative" as discussed by Jakobson, Benveniste, Genette, Todorov, and Barthes are cited in Hayden White, "The Value of Narrativity in the Representation of Real Life," 3.

68. Hayden White, "The Value of Narrativity in the Representation of Real Life," 2-3, italics his.

69. Miriam Silverberg, The Massacre of Koreans after the Great Kanto Earthquake.

70. Ibid., 6 .

71. Sonia Ryang, North Koreans in Japan: Language, Ideology, and Identity.

72. Fung-sok Ro, interview by Hijoo Son, Tokyo, September 8, 2005.

73. In the catalogue, Kang's name is incorrectly printed. Min mistakenly identifies Chŏngsuk Kang as Yŏngsuk Kim. Fungsok Ro confirms that there is no Yŏngsuk Kim in the Areum association.

74. Wonju Lim, interview by Hijoo Son, Los Angeles, California, May 19, 2002.

75. Jennifer Moon, interview by Hijoo Son, Los Angeles, California, May 19, 2002.

76. Mark W. Roskill and David Carrier, Truth and Falsehood in Visual Images.

77. Ibid., 81.

78. Ibid., 80 .

79. I have been in contact with Lina Kim via e-mail, and she has agreed to an interview once her busy schedule permits it.

80. Yong Soon Min, “Certain Latitudes,” 26.

81. Ibid.

82. Ibid., 18.

83. Linda Hutcheon, A Poetics of Postmodernism: History, Theory, and Fiction, 46. I thank Tim Tangherlini for this source.

84. Ibid., 42, italics mine.

\section{BIBLIOGRAPHY}

Anderson, Benedict. Imagined Communities: Reflections on the Origin and Spread of Nationalism. London: Verso, 1993.

Baker, Don. "Introduction." In Religions of Korea in Practice, edited by Robert E. Buswell Jr., 1-29. Princeton, NJ: Princeton University Press, 2006.

Chŏn Chŏnho. "Chungguk Yŏnbyŏn Chosŏnjok misul ŭi hyŏnhwang: Yŏnbyŏn Chosŏnjok ŭi p'ungsŭp kwa misul ŭi sŏnggyŏk chungsim ŭro" [A study on the actual status of the art of the Chosonn race in Yanbian China]. Ph.D. diss., Yanbian Taxue, 1993.

Chun Kyŏng-soo. "Policy for Five Million Overseas Koreans.” Korea Focus 2, no. 6 (1994): 59-65. 
Chung, Tae Shin. "Making History in the Trench City of Kwangju: The Dialectic of Class and Cultural Conflicts in South Korea." Ph.D. diss., Michigan State University, 1991.

Duncan, John B. "Protonationalism in Premodern Korea." In Perspectives on Korea, edited by Sang-oak Lee and Duk-soo Park, 198-221. Sydney: Wild Peony Press, 1988.

Em, Henry H. "Minjok as a Modern and Democratic Construct: Sin Ch'aeho's Historiography." In Colonial Modernity in Korea, edited by Gi-Wook Shin and Michael Robinson, 336-61. Boston, MA: Harvard University Asia Center, 1999.

Finkelstein, Norman G. The Holocaust Industry: Reflections of the Exploitation of Jewish Suffering. London: Verso, 2000.

Gell, Alfred. Art and Agency: An Anthropological Theory. Oxford, NY: Oxford University Press, 1998.

Hoerder, Dirk. Cultures in Contact: World Migrations in the Second Millennium. Durham, NC: Duke University Press, 2002.

Hutcheon, Linda. A Poetics of Postmodernism: History, Theory, and Fiction. New York: Routledge, 1988.

Im Chihyŏn [Lim, Jie-Hyun], Pak Noja, Yi Chin'gyŏng, Chŏng Taham, and Hong Yanghŭi. Kŭndae Han'guk: "Cheguk” kwa "minjok" kyoch'aro [Modern Korea: Crossroads of empire and nation]. Sŏul: Ch'aek kwa Hamkke, 2011.

Joselit, David. "Ring of Fire: Interview with Joe Lewis and Yong Soon Min." Art Journal 57, no. 4 (1998): 86-89.

Kim, Elaine, Margo Machida, and Sharon Mizota, eds. Fresh Talk, Daring Gazes: Conversations on Asian American Art. Berkeley and Los Angeles: University of California Press, 2003.

Kim, Ho-Ki, and Jongil Park. "Renegade Region or the Center of New Nation? Regionalism and Ethnic Nationalism during the Democratization of South Korea." In Korean Identity: Past and Present. Unpublished Conference Volume, Yonsei and Stanford Universities, 2004.

Kim Kyohŏn. Sindan silgi [Veritable records of the spirit of Tan'gun]. Kyŏngsŏng: Taejonggyo ponbu, 1914.

Kim Manhŭm. Han'guk chŏngch 'i ŭi chae insik: minjujuŭi chiyǒkjuŭi chibang chach 'i [Revision of Korean politics: Democracy, regionalism, and regional autonomy]. Sŏul: P'ulbit, 1997.

Kim, Samuel. "Korea's Globalization Drive: An Assessment." Joint U.S.-Korea Academic Studies 10 (2000): 83-84.

Kim Sangho. "2000 Kwangju biennalle ŭi chiyŏk kyŏngje p'agŭp hyogwa” [2000 Kwangju biennale's repercussions in the local economy]. Chiyŏk yŏn'gu 20, no. 3 (2004): 1-16.

Kim Yŏngho. "Tong Asia ŭi munhwa chŏngch'esŏng kwa Kwangju biennalle” [Cultural identity of East Asia and the Kwangju biennale]. Hyŏndae misurhak nonmunjip 3 (Winter 1999): 145-73.

Kim, Young Sam. Korea's Quest for Reform and Globalization: Selected Speeches of President Kim Young Sam. Seoul: The Presidential Secretariat, Republic of Korea, 1995. 
Kwŏn Hyŏkt'ae. 'Chae-Il Chosŏnin wa Han'guk sahoe: Han'guk sahoe nŭn chae-Il Chosŏnin ŭl ottŏk'e 'p'yosang' haewannŭn'ga?' [Resident Koreans and Korean society: How did Korean society "represent” resident Koreans?]. Yŏksa pip’yŏng (2007): 234-67.

Lee, Jae-eui. Kwangju Diary: Beyond Death, Beyond the Darkness of the Age. Translated by Kap Su Seol and Nick Mamatas. Los Angeles: University of CaliforniaLos Angeles Asian Pacific Monograph Series, 1999.

Lim, Jie-Hyun. See Im Chihyŏn.

Mercer, Kobena. "Diaspora Culture and the Dialogic Imagination." In Black Frames: Critical Perspectives on Black Independent Cinema, edited by M. Cham and C. Watkins. Cambridge, MA: MIT Press, 1988.

Min, Yong Soon. "Certain Latitudes." In There: Sites of Korean Diaspora, 12-59. Kwangju: Kwangju Biennial Foundation, 2002.

Paek Chisuk. "Kwangju biennalle rŭl kwallamgi: Tasi nŭn chŏch’ŏrŏm purhaenghan kwallamgaek i nawasŏnŭn andoegessumnida" [Notes from Kwangju biennale: Never again can there be another dissatisfied spectator of the Kwangju biennale]. Munhwa kwahak 8 (Winter 1995): 207-18.

Pai, Hyung Il, and Timothy R. Tangherlini. Nationalism and the Construction of Korean Identity. Berkeley, CA: Institute of East Asian Studies, 1998.

Pak Ch'an'gyŏng. "Kwangju biennalle wa pyŏnyŏk” [Kwangju biennale and translation]. Inmul kwa sasang 128 (2008): 78-83.

Pak Sijong. "Kwangju biennalle, tasi t'aeŏnanda" [Kwangju biennale will be reborn]. Kil 5 (1995): 194-97.

Park, Hyun Ok. "Segyehwa: Globalization and Nationalism in Korea." Journal of International Institute 4, no. 1 (1996). http://hdl.handle.net/2027/spo.4750978.0004.105 (accessed January 22, 2002).

Pratt, Keith, and Richard Rutt. Korea: A Historical and Cultural Dictionary. Surrey, UK: Curzon Press, 1999.

Roskill Mark W., and David Carrier. Truth and Falsehood in Visual Images. Amherst: University of Massachusetts Press, 1983.

Roth, Moira. "Traveling Companions/Fractured Worlds." Art Journal 58, no. 2 (1999): 82.

Ryang, Sonia. North Koreans in Japan: Language, Ideology, and Identity. Boulder, CO: Westview Press, 1997.

Sakai, Naoki. "Introduction: Nationality and the Politics of the 'Mother Tongue."' In Deconstructing Nationality, edited by Naoki Saki, Bret de Bary, and Toshio Iyotani, 1-38. Ithaca, NY: East Asia Program, Cornell University, 2005.

Schmid, Andre. Korea between Empires 1895-1919. New York: Columbia University Press, 2002.

Sheffer, Gabriel. "A New Field of Study: Modern Diasporas in International Politics." In Modern Diasporas in International Politics, edited by Gabriel Sheffer, 1-16. London: Croom Helm, 1986.

Shin, Gi-Wook, and Kyung Moon Hwang. Contentious Kwangju: The May 18 Uprising in Korea's Past and Present. Lanham, MD: Rowman and Littlefield Publishers, 2003. 
Shin, Haeran. "Cultural Festivals and Regional Identities in South Korea." Environment and Planning D: Society and Space 22 (2004): 619-32.

Silverberg, Miriam. "The Massacre of Koreans after the Great Kanto Earthquake." M.A. thesis, Georgetown University, 1979.

Sŏ Kyŏngsik. Nanmin wa kungmin sai: Chae-Il Chosŏnin Sŏ Kyŏngsik ŭi sayu wa sŏngch'al [Between refugee and citizen: Thoughts and reflections of resident Korean in Japan Sǒ Kyǒngsik]. Translated by Im Sŏngmo and Yi Kyusu. Kyŏnggi-do, P'aju: Tolbegae, 2006.

Son Hŭiju [Son, Hijoo]. 'Haeoe tongp'o rŭl kyŏnyanghan ch'oguk kajŏk chŏngch'aek: munhwa chŏngch'esŏng hyŏngsŏng, segyehwa, 'kat'un minjok' ŭrosŏ ŭi 'tongp'o' ranŭn kaenyŏm" [Transnational policy toward overseas Koreans: Cultural identity construction, segyehwa, and the ideology of tonp'o as "co-ethnics"]. In Kündae Han'guk: "Cheguk" kwa "minjok" kyoch'aro [Modern Korea: Crossroads of empire and nation], edited by Yim Chihyŏn, Pak Noja, Yi Chin'gyŏng, Chŏng Taham, and Hong Yanghŭi, 364-93. Sŏul: Ch'aek kwa Hamkke, 2011.

Um, Hae-kyung. "Community, Identity, and Performing Arts: The Korean Diaspora in the Former Soviet Union and China." In Diasporas and Interculturalism in Asian Performing Arts: Translating Traditions, edited by Hae-kyung Um. London: Routledge Curzon, 2005.

White, Hayden. "The Value of Narrativity in the Representation of Real Life." In On Narrative, edited by W. J. T. Mitchell. Chicago: University of Chicago Press, 1980.

Yi Hŭich'an. 'Megaibent'ŭ ŭi chiyŏk kyŏngje hyogwa ch'ujŏng pangbŏp yŏn'gu: 2000 Kwangju biennalle rŭl sarye ro" [Estimating the direct economic impact of mega-events: Case of the 2000 Kwangju biennale]. Kwangwanghak yŏn'gu 25, no. 2 (2001): 155-76.

Yi Kwanggyu. Segye üi Hanminjok [Overseas Koreans of the world, vols, 1-10]. Sŏul: Sŏul Taehakkyo Ch’ulp'anbu, 1996.

Yi Pyŏngdo. “Chosŏn minjok ŭi tanilsŏng”' [Chosŏn people's homogeneity]. Sinch 'ŏnji 1, no. 8 (1956): 8-15.

Yi Sŭngnyŏng. "Sŏk Hŭiman ŭi saengoe wa chakp'um segye e kwanhan yŏn'gu" [A study on Shi Xi-Man's life and art]. Ph.D. diss., Wŏn'gwang Taehakkyo, 2006.

Yun Injin. K'orian Tiasŭp'ora: chaeoe Hanin ŭi iju chŏgŭng, chǒngch'esǒng [Korean diaspora: Identity, assimilation and acculturation in the migration of overseas Koreans]. Sŏul: Koryŏ Taehakkyo Ch'ulp'anbu, 2004.

Yun Pŏmmo. "Isan ŭi ttang, isandoen chŏnsi kihoek" [Scattered people, scattered exhibition]. Space, July (2002): 78-79. Reprinted in "Special Feature: 2002 Kwangju Biennale," Art and Culture 3, no. 5 (May 2002): 60-95.

Yun Pyŏnguk. Nara pakkesŏ nara ch'ajanne: Miju Hanin tongnip undongsa ǔi chae insik [Getting Korea back outside that you lost inside: Rethinking the Korean independence movement in America]. Sŏul: Pagyǒngsa, 2006.

Yu Yŏngguk. "Kwangju biennalle wa chiyŏk kyŏngje" [Kwangju biennale and the local economy]. Kyŏngyŏng chŏngbo (1995): 33-39. 